\title{
Assessment of Nonpoint Source Chemical Loading Potential to Watersheds Containing Uranium Waste Dumps Associated with Uranium Exploration and Mining, Browns Hole, Utah
}

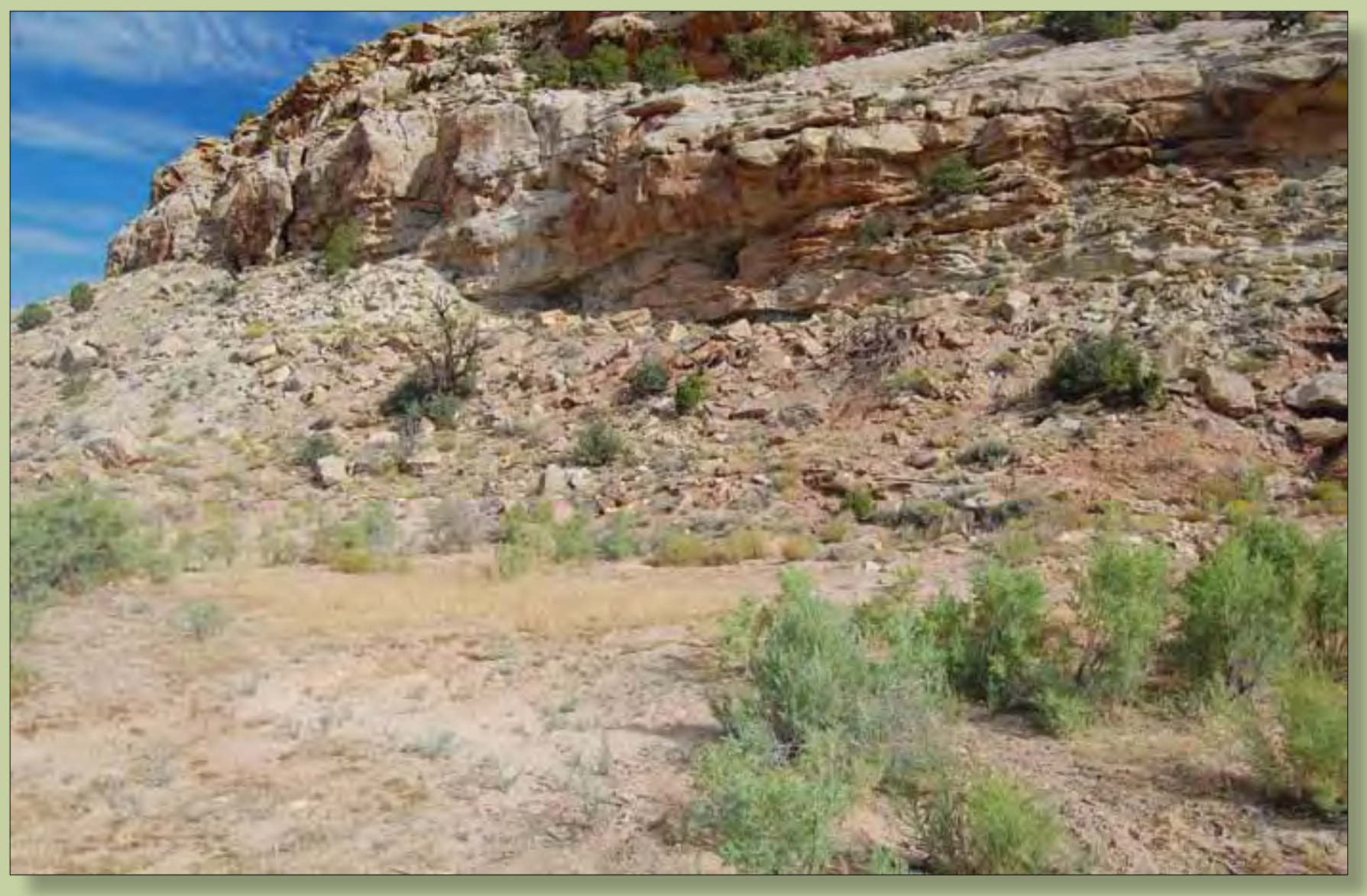

Prepared in cooperation with the Bureau of Land Management

Scientific Investigations Report 2011-5230 
Cover: Photograph looking northeast near site BH-46, San Juan County, Utah. By Kimberly R. Beisner in August 2008. 


\section{Assessment of Nonpoint Source Chemical Loading Potential to Watersheds Containing Uranium Waste Dumps Associated with Uranium Exploration and Mining, Browns Hole, Utah}

By Thomas M. Marston, Kimberly R. Beisner, David L. Naftz, and Terry Snyder

Prepared in cooperation with the Bureau of Land Management

Scientific Investigations Report 2011-5230 


\section{U.S. Department of the Interior \\ KEN SALAZAR, Secretary \\ U.S. Geological Survey \\ Marcia K. McNutt, Director}

\section{U.S. Geological Survey, Reston, Virginia: 2012}

For more information on the USGS — the Federal source for science about the Earth, its natural and living resources, natural hazards, and the environment, visit http://www.usgs.gov or call 1-888-ASK-USGS.

For an overview of USGS information products, including maps, imagery, and publications, visit http://www.usgs.gov/pubprod

To order this and other USGS information products, visit http://store.usgs.gov

Any use of trade, product, or firm names is for descriptive purposes only and does not imply endorsement by the U.S. Government.

Although this report is in the public domain, permission must be secured from the individual copyright owners to reproduce any copyrighted materials contained within this report.

Suggested citation:

Marston, T.M., Beisner, K.R., Naftz, D.L., and Snyder, T., 2012, Assessment of nonpoint source chemical loading potential to watersheds containing uranium waste dumps associated with uranium exploration and mining, Browns Hole, Utah: U.S. Geological Survey Scientific Investigations Report 2011-5230, 36 p. 


\section{Contents}

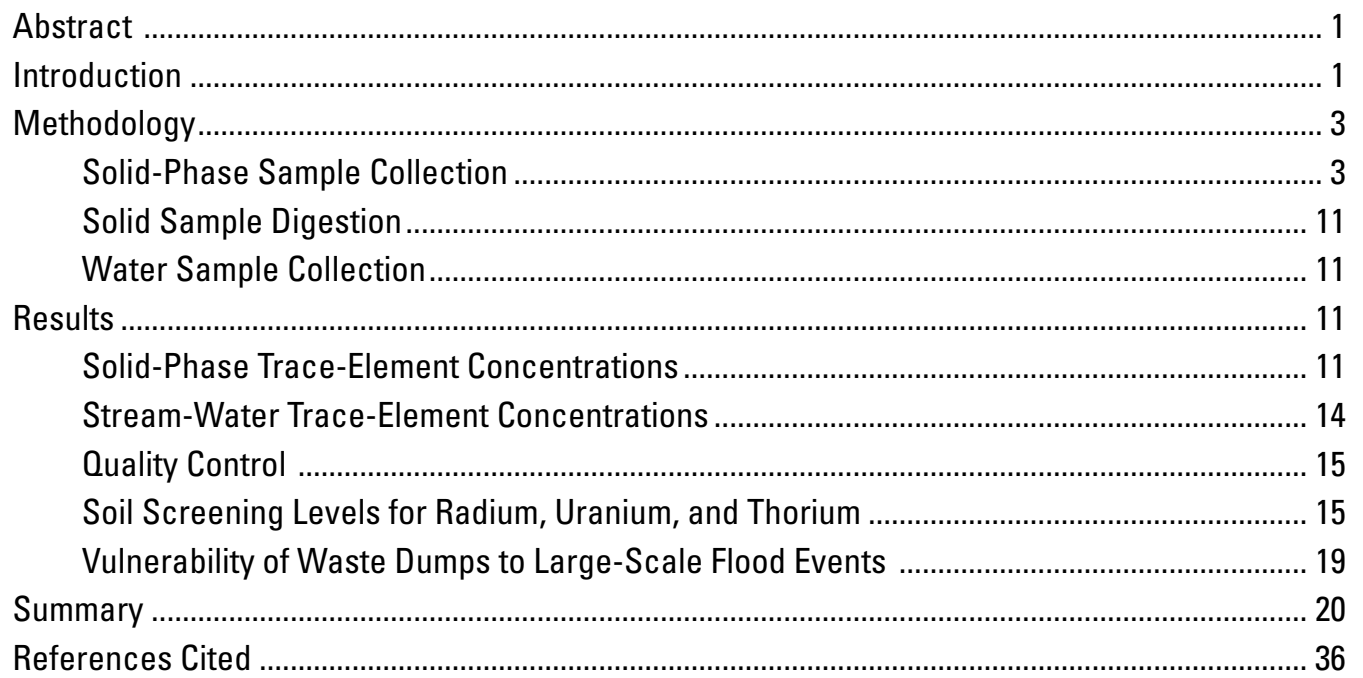

\section{Figures}

1. Map showing location of the abandoned mine lands study area in Browns Hole, Utah .... 2

2. Index map of uranium waste dump, streambed sediment, undisturbed geologic background, and stream-water sample sites in Browns Hole, Utah ................................. 4

3. Map 1a showing sample locations and associated concentrations of total radium in solid-phase material from uranium waste dump, streambed sediment, and geologic background sites

4. Map 1a showing sample locations and associated concentrations of total uranium in solid-phase material from uranium waste dump, streambed sediment, and geologic background sites

5. Map 1b showing sample locations and associated concentrations of total radium in solid-phase material from uranium waste dump, streambed sediment, and geologic background sites

6. Map 1b showing sample locations and associated concentrations of total uranium in solid-phase material from uranium waste dump, streambed sediment, and geologic background sites

7. Map 1c showing sample locations and associated concentrations of total radium in solid-phase material from uranium waste dump, streambed sediment, and geologic background sites

8. Map 1c showing sample locations and associated concentrations of total uranium in solid-phase material from uranium waste dump, streambed sediment, and geologic background sites

9. Bar graphs showing concentrations of selected trace elements in solid-phase material from 20 uranium mine waste dump sites in Browns Hole, Utah 
10. Graphs showing solid-phase sediment transects of BH-36, BH-40, and BH-49 and associated downstream streambed sediment for total radium, uranium, vanadium, and arsenic concentrations

11. Chart of selected natural decay series: uranium, radium, and thorium 18

12. Bar graph showing concentration of radium from 20 waste dump samples collected from Browns Hole, Utah

\section{Tables}

1. U.S. Geological Survey site identification and associated Bureau of Land Management Tag Numbers for abandoned uranium mines selected for this study, Browns Hole, Utah

2. Field parameters measured in Muleshoe Creek on August 13, 2008, Browns Hole, Utah

3. Chemical analysis of total extractible-from-sediment samples for major-ion and trace-element concentrations from uranium waste dump, undisturbed geologic background, and dry ephemeral streambed samples, Browns Hole, Utah

4. U.S. Environmental Protection Agency drinking-water-quality standards and aquatic life water-quality standards

5. Chemical analysis of filtered water samples collected on August 13,2008 , from Muleshoe Creek, Browns Hole, Utah

6. Chemical analysis of unfiltered water samples collected on August 13, 2008, from Muleshoe Creek, Browns Hole, Utah

7. Drainage area characteristics associated with uranium waste dump samples, Browns Hole, Utah 


\section{Conversion Factors and Abbreviations}

\begin{tabular}{|c|c|c|}
\hline Multiply & By & To obtain \\
\hline \multicolumn{3}{|c|}{ Length } \\
\hline centimeter (cm) & 0.3937 & inch (in.) \\
\hline meter (m) & 3.281 & foot (ft) \\
\hline kilometer (km) & 0.6214 & mile (mi) \\
\hline \multicolumn{3}{|c|}{ Area } \\
\hline square kilometer $\left(\mathrm{km}^{2}\right)$ & 0.3861 & square mile $\left(\mathrm{mi}^{2}\right)$ \\
\hline \multicolumn{3}{|c|}{ Volume } \\
\hline cubic meter $\left(\mathrm{m}^{3}\right)$ & 35.31 & cubic foot $\left(\mathrm{ft}^{3}\right)$ \\
\hline liter (L) & 61.02 & cubic inch $\left(\right.$ in $\left.^{3}\right)$ \\
\hline \multicolumn{3}{|c|}{ Mass } \\
\hline gram (g) & 0.03527 & ounce, avoirdupois (oz) \\
\hline
\end{tabular}

Temperature in degrees Celsius $\left({ }^{\circ} \mathrm{C}\right)$ may be converted to degrees Fahrenheit $\left({ }^{\circ} \mathrm{F}\right)$ as follows:

${ }^{\circ} \mathrm{F}=\left(1.8 x^{\circ} \mathrm{C}\right)+32$

Temperature in degrees Fahrenheit $\left({ }^{\circ} \mathrm{F}\right)$ may be converted to degrees Celsius $\left({ }^{\circ} \mathrm{C}\right)$ as follows:

${ }^{\circ} \mathrm{C}=\left({ }^{\circ} \mathrm{F}-32\right) / 1.8$

Vertical coordinate information is referenced to the North American Vertical Datum of 1988 (NAVD 88)

Horizontal coordinate information is referenced to the North American Datum of 1983 (NAD 83)

Altitude, as used in this report, refers to distance above the vertical datum.

Specific conductance is given in microsiemens per centimeter at 25 degrees Celsius $(\mu \mathrm{S} / \mathrm{cm}$ at $\left.25^{\circ} \mathrm{C}\right)$. 


\title{
Abbreviations and Acronyms
}

\author{
(Clarification or additional information given in parentheses) \\ AML abandoned mine lands \\ BG background \\ BH Browns Hole \\ CERCLA Comprehensive Environmental Response, Compensation, and Liability Act of 1980 \\ (Superfund) \\ GIS geographic information system \\ HDPE high density polyethylene \\ ID identification \\ SED stream sediment \\ Organizations
}

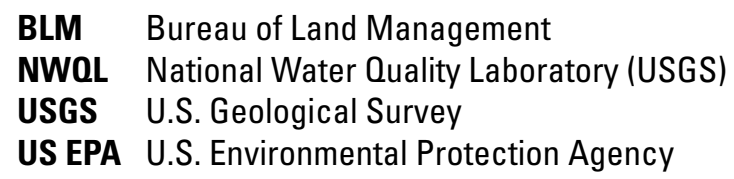

Units of measurement

\begin{tabular}{|c|c|}
\hline C & Celsius \\
\hline $\mathbf{c m}$ & centimeter $\left(10^{-2}\right.$ meter $)$ \\
\hline $\mathbf{f t}$ & foot (feet) \\
\hline $\mathrm{ft}^{3} / \mathrm{s}$ & cubic feet per second \\
\hline $\mathbf{g}$ & gram \\
\hline $\mathrm{g} / \mathrm{m}^{3}$ & grams per cubic meter \\
\hline $\mathrm{g} / \mathrm{yr}$ & grams per year \\
\hline in. & inch \\
\hline $\mathbf{L}$ & liter \\
\hline $\mathbf{m}^{3} / \mathbf{y}$ & cubic meters per year \\
\hline mi & mile \\
\hline $\mathbf{m i}^{2}$ & square mile \\
\hline $\mathbf{m L}$ & milliliter (10-3 liter) \\
\hline mm & millimeter $\left(10^{-3}\right.$ meter $)$ \\
\hline mrem & millirem $\left(10^{-3}\right.$ rem $)$ \\
\hline $\mathbf{m V}$ & millivolt \\
\hline $\mathrm{pCi} / \mathrm{g}$ & picocurie(s) per gram (10-12 curie) \\
\hline ppm & parts per million \\
\hline pCi/L & picocurie(s) per liter \\
\hline$\mu \mathrm{g} / \mathrm{L}$ & microgram(s) per liter $\left(10^{-6}\right.$ grams per liter) \\
\hline
\end{tabular}

\begin{tabular}{cl}
\multicolumn{2}{c}{ Chemical Elements } \\
Ag & Silver \\
Al & Aluminum \\
As & Arsenic \\
Ba & Barium \\
Be & Beryllium \\
Bi & Bismuth \\
Ca & Calcium \\
Cd & Cadmium \\
Ce & Cerium \\
Co & Cobalt \\
Cr & Chromium
\end{tabular}

$\begin{aligned} \text { Cs } & \text { Cesium } & \text { Na } & \text { Sodium } \\ \mathbf{C u} & \text { Copper } & \mathbf{N b} & \text { Niobium } \\ \mathbf{F e} & \text { Iron } & \mathbf{N i} & \text { Nickel } \\ \mathbf{G a} & \text { Gallium } & \mathbf{P} & \text { Phosphorous } \\ \mathbf{H g} & \text { Mercury } & \mathbf{P b} & \text { Lead } \\ \mathbf{I n} & \text { Indium } & \mathbf{R a} & \text { Radium } \\ \mathbf{K} & \text { Potassium } & \mathbf{R b} & \text { Rubidium } \\ \mathbf{L a} & \text { Lanthanum } & \mathbf{S} & \text { Sulfur } \\ \mathbf{L i} & \text { Lithium } & \text { Sb } & \text { Antimony } \\ \mathbf{M g} & \text { Magnesium } & \text { Sc } & \text { Scandium } \\ \mathbf{M n} & \text { Manganese } & \text { Se } & \text { Selenium } \\ \mathbf{M o} & \text { Molybdenum } & \text { Sn } & \text { Tin }\end{aligned}$

Sr Strontium

Te Tellurium

Th Thorium

Ti Titanium

Tl Thallium

U Uranium

V Vanadium

W Tungsten

Y Yttrium

Zn Zinc 


\title{
Assessment of Nonpoint Source Chemical Loading Potential to Watersheds Containing Uranium Waste Dumps Associated with Uranium Exploration and Mining, Browns Hole, Utah
}

\author{
By Thomas M. Marston, Kimberly R. Beisner, David L. Naftz, and Terry Snyder
}

\section{Abstract}

During August of 2008, 35 solid-phase samples were collected from abandoned uranium waste dumps, undisturbed geologic background sites, and adjacent streambeds in Browns Hole in southeastern Utah. The objectives of this sampling program were (1) to assess impacts on human health due to exposure to radium, uranium, and thorium during recreational activities on and around uranium waste dumps on Bureau of Land Management lands; (2) to compare concentrations of trace elements associated with mine waste dumps to natural background concentrations; (3) to assess the nonpoint source chemical loading potential to ephemeral and perennial watersheds from uranium waste dumps; and (4) to assess contamination from waste dumps to the local perennial stream water in Muleshoe Creek. Uranium waste dump samples were collected using solid-phase sampling protocols. Solid samples were digested and analyzed for major and trace elements. Analytical values for radium and uranium in digested samples were compared to multiple soil screening levels developed from annual dosage calculations in accordance with the Comprehensive Environmental Response, Compensation, and Liability Act's minimum cleanup guidelines for uranium waste sites. Three occupancy durations for sites were considered: 4.6 days per year, 7.0 days per year, and 14.0 days per year. None of the sites exceeded the radium soil screening level of 96 picocuries per gram, corresponding to a 4.6 days per year exposure. Two sites exceeded the radium soil screening level of 66 picocuries per gram, corresponding to a 7.0 days per year exposure. Seven sites exceeded the radium soil screening level of 33 picocuries per gram, corresponding to a 14.0 days per year exposure. A perennial stream that flows next to the toe of a uranium waste dump was sampled, analyzed for major and trace elements, and compared with existing aquatic-life and drinking-water-quality standards. None of the water-quality standards were exceeded in the stream samples.

\section{Introduction}

Browns Hole is located in southeastern Utah in San Juan County, 18 mi south of the town of Moab and covers approximately $36 \mathrm{mi}^{2}$ of primarily Bureau of Land Management (BLM) lands (fig. 1) that have altitudes ranging from 5,600 to $6,500 \mathrm{ft}$ above sea level. Exposed rocks range in age from the Permian Cutler Formation to the Jurassic Navajo Sandstone. Most of the land is covered by ephemeral drainages that only contribute runoff during rainfall and snowmelt events.

The lowland canyons are characterized by mild winters, with an average maximum daily temperatures of $42^{\circ} \mathrm{F}$, and hot summers, with average maximum daily temperature of $98^{\circ} \mathrm{F}$. Most of the precipitation falls as rain from convective thunderstorms that typically occur between August and October. This arid region receives approximately 6 to 8 in. of precipitation in the lower elevations and approximately 8 to 10 in. of precipitation in the higher elevations (Natural Resources Conservation Service, 1998).

Browns Hole is one of several areas in southern Utah that experienced uranium mining and exploration in the 1950s. Most of the mines and exploration activities extracted material from the Salt Wash Sandstone Member of the Jurassic Morrison Formation, which is overlain by the Cretaceous Burro Canyon Formation and is underlain by the Slickrock Member of the Jurassic Entrada Sandstone (Gloyn and others, 1995). Currently (2010), thousands of abandoned uranium waste dumps exist throughout the state of Utah, with many of the properties located on lands managed by the BLM. Sixty-three uranium mine adits have been inventoried by the BLM throughout the Browns Hole area (Terry Snyder, Bureau of Land Management, written commun., 2008). Of the 63 inventoried adits, 20 adits were selected for sampling on the basis of size and ease of access (table 1). Abandoned uranium waste dumps associated with the previously mentioned adits present unique characteristics that make it difficult to quantify nonpoint source pollution contributions to specific watersheds. These characteristics include (1) locations that are primarily in watersheds with ephemeral streams, (2) radioactive sands and fine particulates that persist for hundreds of thousands of years, (3) intense rainfall and snowmelt events that can mobilize and transport mine waste with associated radioactive 


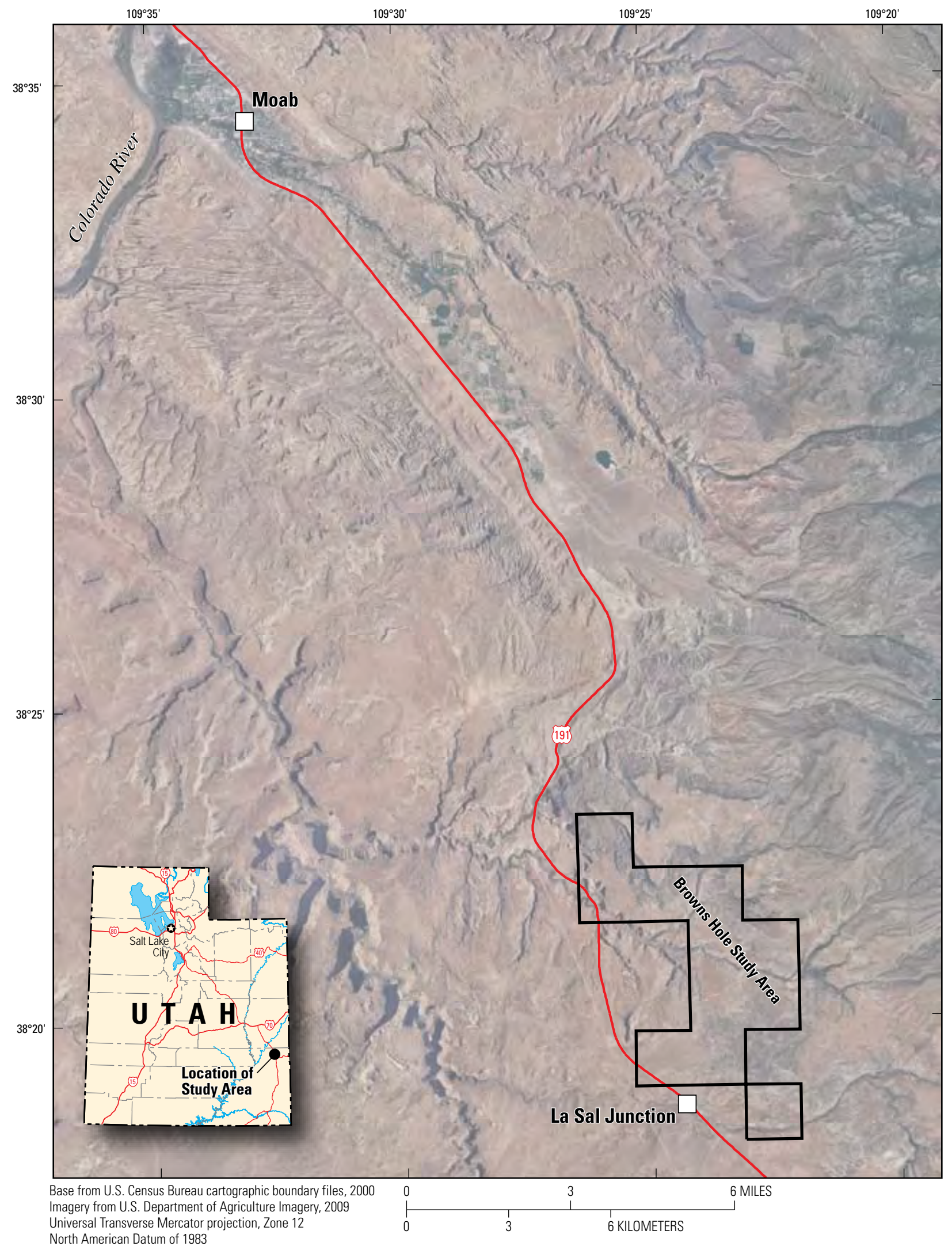

Figure 1. Location of the abandoned mine lands study area in Browns Hole, Utah. 
Table 1. U.S. Geological Survey site identification and associated Bureau of Land Management Tag Numbers for abandoned uranium mines selected for this study, Browns Hole, Utah.

[Abbreviations: Site ID, site identification; BLM, Bureau of Land Management; BH, Browns Hole; HO, horizontal opening; IO, inclined opening]

\begin{tabular}{|c|c|c|}
\hline Site ID & $\begin{array}{c}\text { USGS } \\
\text { site number }\end{array}$ & $\begin{array}{c}\text { BLM } \\
\text { tag number }\end{array}$ \\
\hline $\mathrm{BH}-2$ & 382228109254301 & 4282307HO001 and HO002 \\
\hline BH-26 & 382153109241801 & 4282317IO001 \\
\hline BH-27 & 382157109241601 & 4282317IO002 \\
\hline BH-28 & 382146109244901 & 4282317HO001 and HO002 \\
\hline BH-30 & 382146109241801 & $4282317 \mathrm{HO} 003$ and HO004 \\
\hline BH-32 & 382147109241901 & 4282317HO005 \\
\hline BH-33 & 382149109242701 & $4282317 \mathrm{HO} 006$ and HO007 \\
\hline BH-35 & 382224109253901 & $4282318 \mathrm{HO} 001$ \\
\hline BH-36 & 382220109253501 & $4282318 \mathrm{HO} 002$ \\
\hline BH-37 & 382049109230001 & $4282322 \mathrm{HO} 001$ \\
\hline $\mathrm{BH}-40$ & 382048109225701 & $4282322 \mathrm{HO} 002$ through $\mathrm{HO} 007$ \\
\hline $\mathrm{BH}-46$ & 382009109233101 & 4282328HO001 through HO003 \\
\hline BH-49 & 382008109233101 & 4282328HO004 through HO006 \\
\hline BH-52 & 381903109232401 & 4282333HO001 through HO003 \\
\hline $\mathrm{BH}-54$ & 381907109232501 & 4282333 HO004 \\
\hline BH-58 & 381945109231901 & 4282333HO005 through HO008 \\
\hline BH-59 & 381849109224401 & 4292303 HO001 \\
\hline BH-60 & 381848109224301 & $4292303 \mathrm{HO} 002$ \\
\hline BH-62 & 381849109225801 & $4292303 \mathrm{HO} 003$ and HO004 \\
\hline BH-63 & 381849109230001 & $4292303 \mathrm{HO} 005$ \\
\hline
\end{tabular}

material and trace elements long distances during relatively short time periods, and (4) remote locations that do not allow for cost effective water and suspended-sediment sampling during intermittent rainfall and snowmelt runoff events.

The Browns Hole area is bisected by a perennial stream, Muleshoe Creek, which flows past the toe of an abandoned uranium waste dump (fig. 2). The site is further complicated by the presence of water flowing out of adits and onto the uranium waste dump primarily during the spring season. Muleshoe Creek dries up downstream of the mining area and resurfaces near U.S. Highway 191 to the west.

Sample collection from uranium waste dump sites during August 2008 was completed by the U.S. Geological Survey (USGS) in cooperation with the BLM. The primary objective of this report is to present results of chemical analyses of both solid-phase and stream-water samples collected at abandoned mine sites for assessment of risk to human health from exposure to radioactive elements in waste dump piles. The first objective is similar to a study completed by the U.S. Environmental Protection Agency (2008), which investigated potential human health, geographic, and environmental issues related to abandoned uranium mines in southeastern Utah. The second objective is to assess the nonpoint source chemical loading potential from uranium waste dump sites to ephemeral and perennial watersheds for use in setting remediation priorities. The third objective is to compare trace-element concentrations associated with waste dump sites to natural background areas. The fourth objective is to assess possible contamination by waste dump sites adjacent to the local perennial stream, Muleshoe Creek.

\section{Methodology}

\section{Solid-Phase Sample Collection}

Thirty-five samples (20 from uranium waste dump sites, 8 from streambed sites, and 7 from geologic background sites) were collected in August 2008. The general locations of the uranium waste dump, geologic background, and streambed sites that were sampled are shown in figure 2, and more detailed maps of the sampled sites are shown in figures 3-8. Because the uranium waste dumps had steep slopes, sampling generally took place from the safest and most accessible location, which was typically at the top of waste dumps. Geologic background samples were collected in the same geologic layer adjacent to sampled uranium waste dump sites. Streambed samples were collected from ephemeral stream channels downstream from sampled uranium waste dump sites.

A modified version of the solid-phase sampling methods outlined in Smith and others (2000) and Hageman and Briggs (2000) was used to collect samples from the uranium waste dump and undisturbed geologic background sites. Samples consisted of 30 scoops of soil collected using a plastic trowel from the top $5 \mathrm{~cm}$ of soil depth. One scoop is approximately equal to 7 in. ${ }^{3}$. Scoops of soil for each sample were compiled into 2-gallon Ziploc ${ }^{\circledR}$ bags and labeled. Streambed samples, consisting of 10 scoops of sediment from the top $5 \mathrm{~cm}$ of depth, were collected along ephemeral stream channels using a plastic trowel.

Samples from the uranium waste dump sites were labeled BH (for "Browns Hole") and then numbered in sequential order from the time when the samples were collected. Undisturbed geologic background site samples were labeled $\mathrm{BH}$, followed by the number of the closest waste dump site and the letters BG (for "background"). Streambed site samples were labeled $\mathrm{BH}$, followed by the number of the upstream waste dump site and the letters SED (for "sediment"), with sample locations labeled sequentially with distance from the source waste rock pile. BH sample identifications that were assigned to the abandoned uranium mines by the USGS have been paired with the site identifications assigned by the BLM and can be viewed in table 1 .

All sampling equipment was thoroughly cleaned in the field between each sampling location. A plastic multi-purpose sprayer was used to thoroughly wash plastic trowels three times with de-ionized water; trowels were then wiped with a clean paper towel and allowed to air dry before use at the next site. 


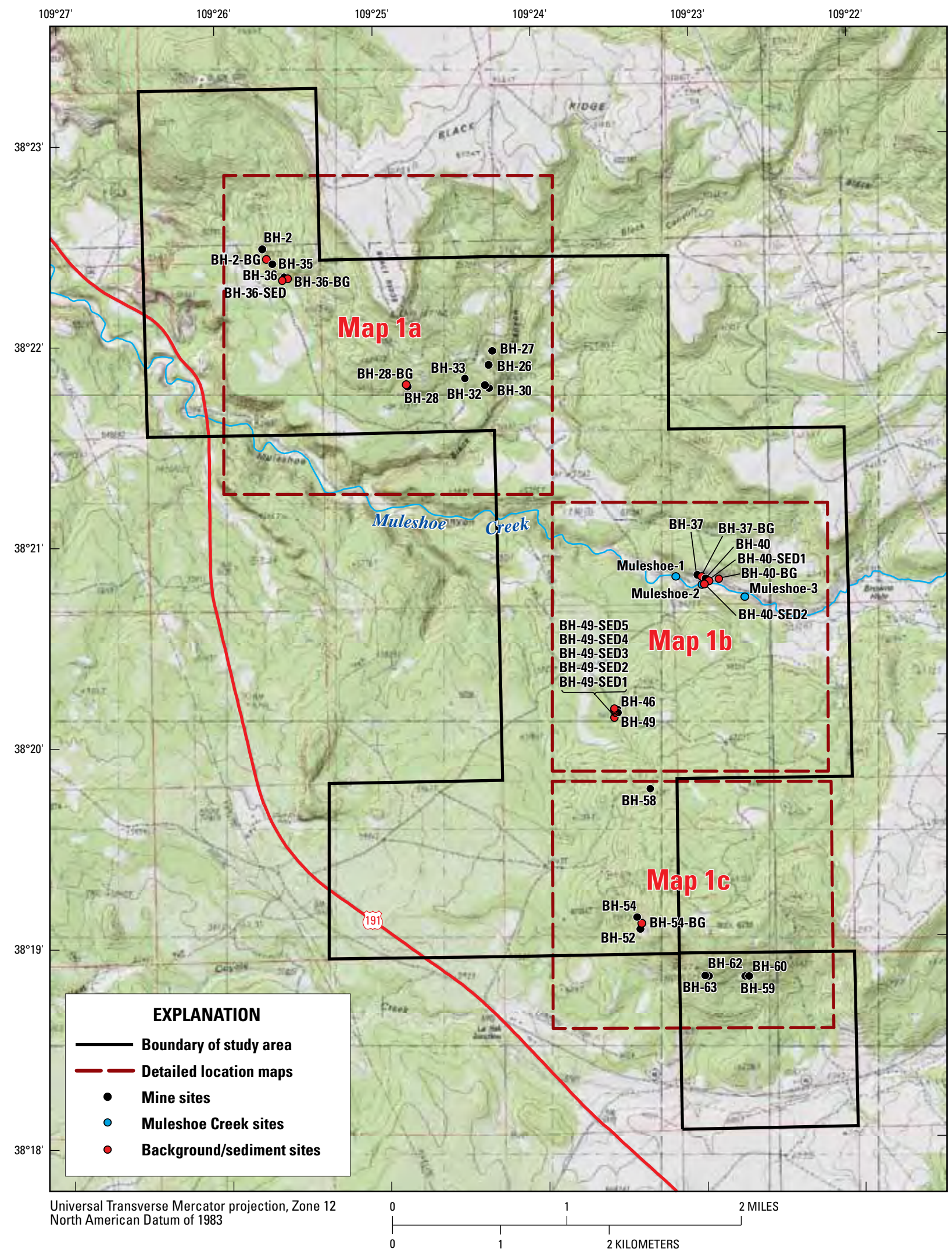

Figure 2. Index map of uranium waste dump, streambed sediment, undisturbed geologic background, and stream-water sample sites in Browns Hole, Utah. 


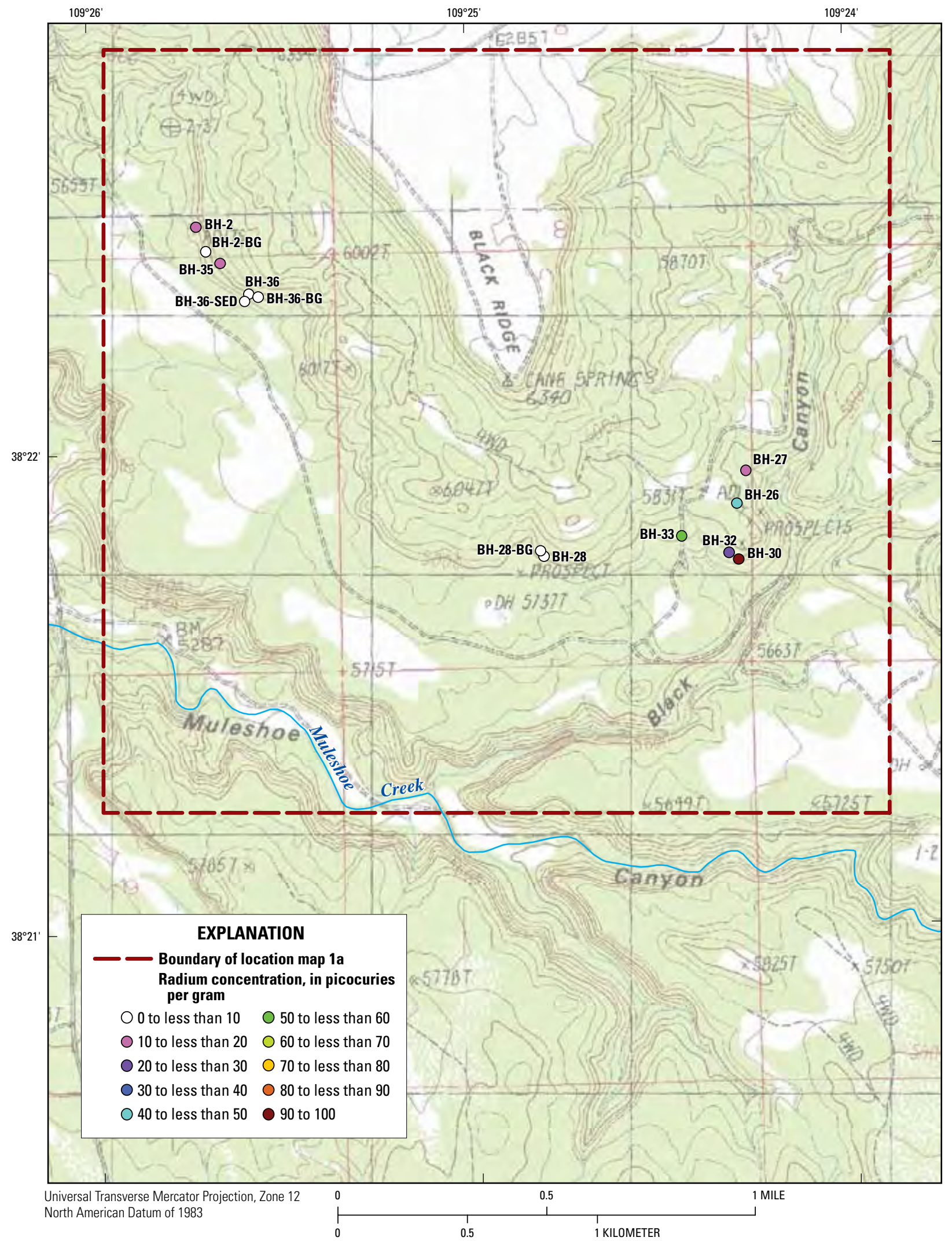

Figure 3. Map 1a showing sample locations and associated concentrations of total radium in solid-phase material from uranium waste dump, streambed sediment, and geologic background sites. 


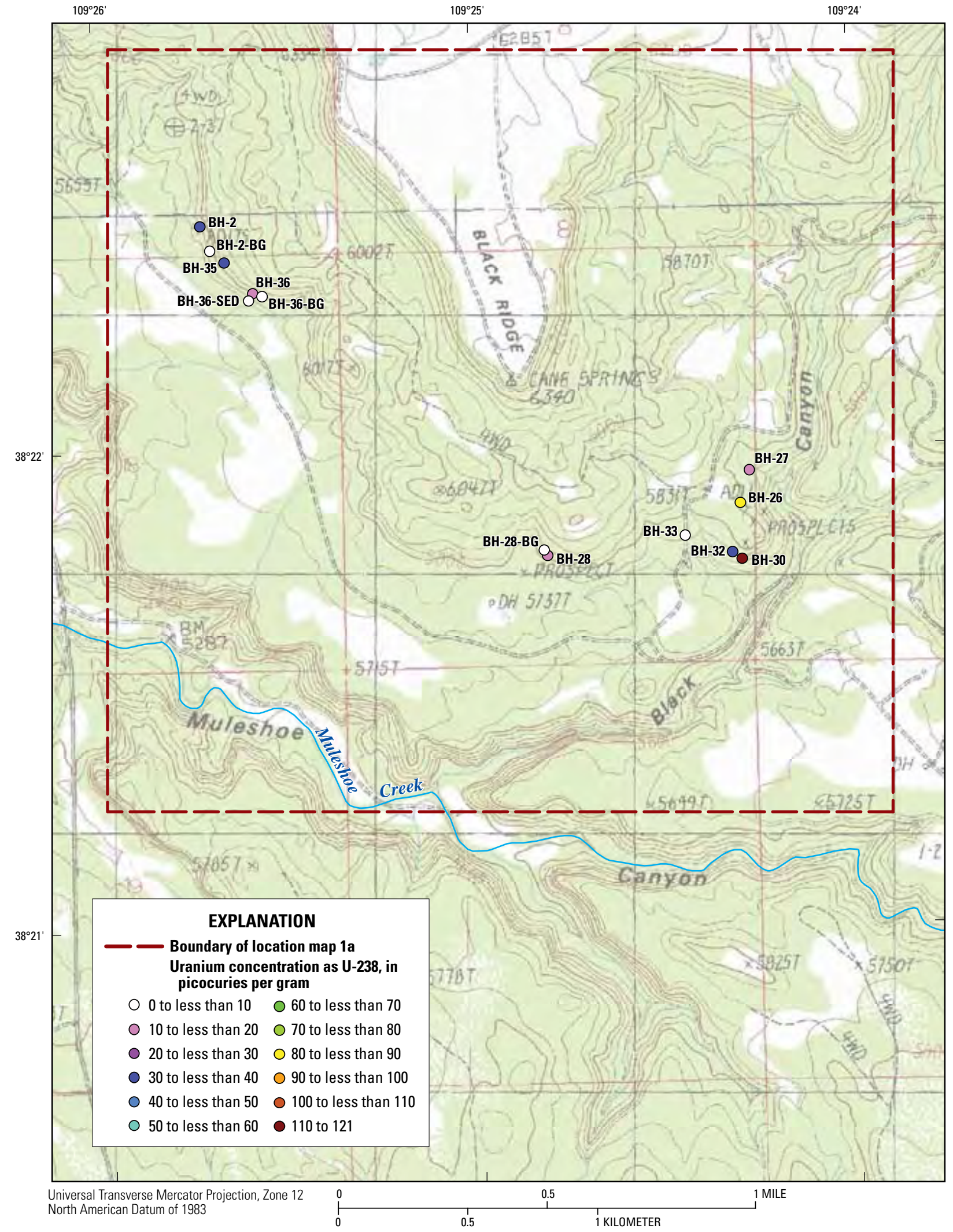

Figure 4. Map 1a showing sample locations and associated concentrations of total uranium in solid-phase material from uranium waste dump, streambed sediment, and geologic background sites. 


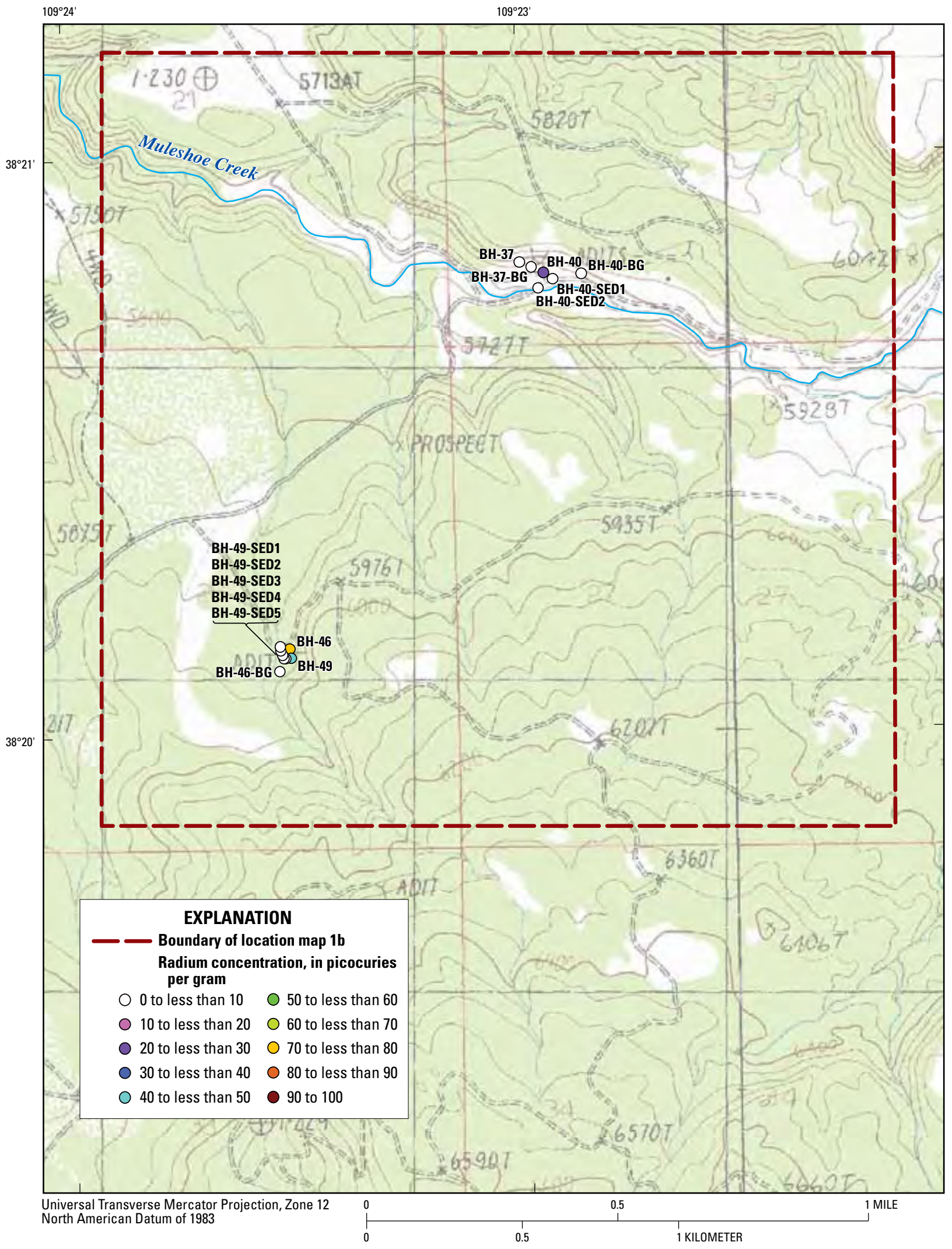

Figure 5. Map 1b showing sample locations and associated concentrations of total radium in solid-phase material from uranium waste dump, streambed sediment, and geologic background sites. 


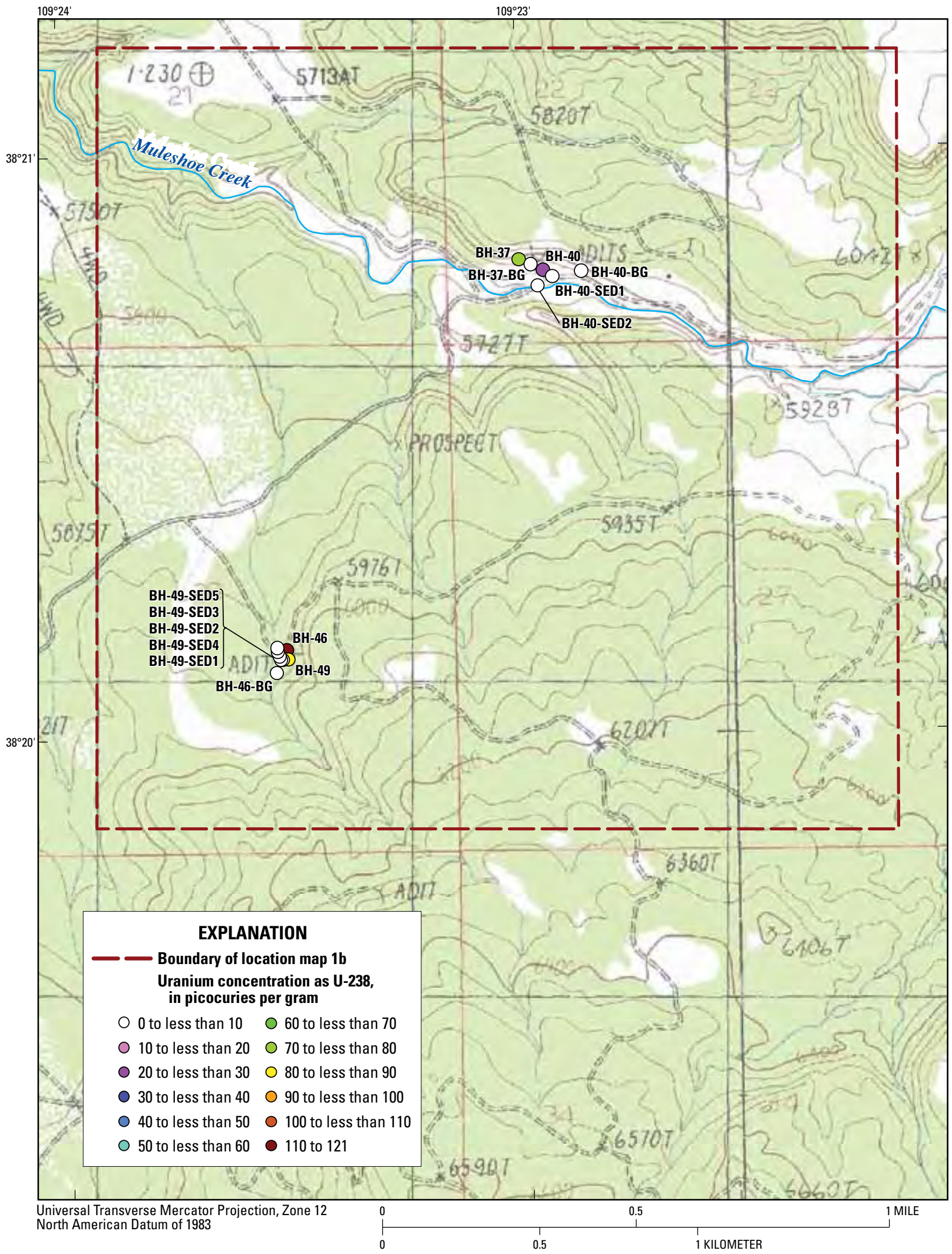

Figure 6. Map 1b showing sample locations and associated concentrations of total uranium in solid-phase material from uranium waste dump, streambed sediment, and geologic background sites. 


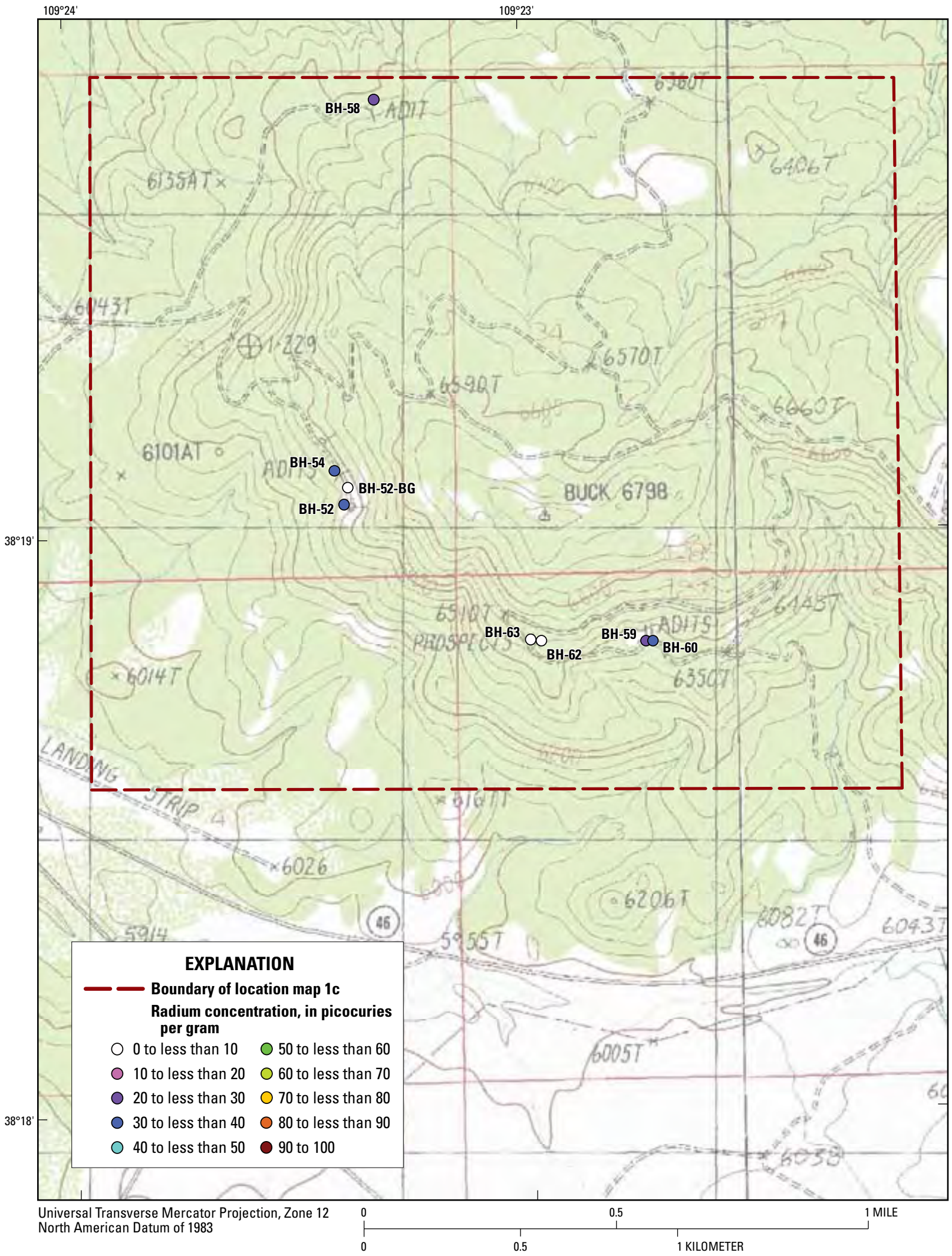

Figure 7. Map 1c showing sample locations and associated concentrations of total radium in solid-phase material from uranium waste dump, streambed sediment, and geologic background sites. 


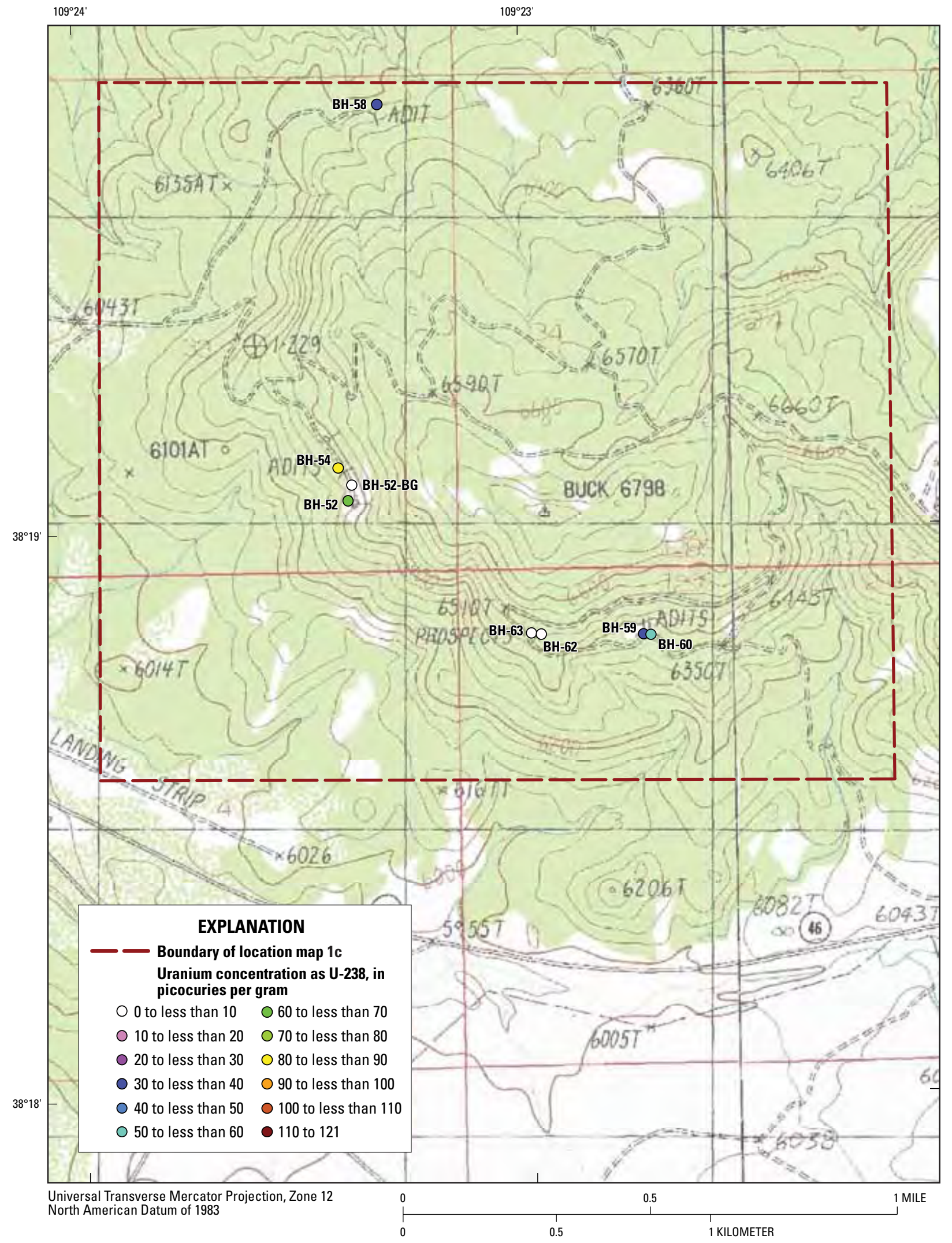

Figure 8. Map 1c showing sample locations and associated concentrations of total uranium in solid-phase material from uranium waste dump, streambed sediment, and geologic background sites. 


\section{Solid Sample Digestion}

Prior to laboratory submission, the uranium waste dump and streambed samples were sieved through a 2-millimeter (mm) mesh (U.S. Sieve No. 10). The fraction of sample passing through the No. 10 sieve was analyzed by the USGS Geologic Division Laboratory for total extractible concentrations of selected trace elements. Forty-two elements (Ag, Al, As, Ba, Be, Bi, Ca, Cd, Ce, Co, Cr, Cs, Cu, Fe, Ga, In, K, La, Li, Mg, Mn, Mo, Na, Nb, Ni, P, Pb, Rb, S, Sb, Sc, Sn, Sr, Te, Th, Ti, Tl, U, V, W, Y, and Zn) were analyzed using inductively coupled plasma-atomic emission spectrometry (ICP-AES) following decomposition of the solid sample using hydrochloric, nitric, perchloric, and hydrofluoric acids at low temperature (Crock and others, 1983). The digested samples are aspirated in the ICP-AES discharge, where the elemental emission signal is measured simultaneously for the forty-two elements. The procedure and analytical performance are presented in Briggs (2002). Selenium was analyzed using hydride generation-atomic absorption spectrophotometry (HG-AAS) following digestion of the solid sample using nitric, hydrochloric, and sulfuric acids (Hageman and others, 2002). Mercury was analyzed using cold vapor-atomic absorption spectrometry (CV-AAS) following digestion of the solid sample using nitric acid and sodium dichromate (Brown and others, 2002). Radium was analyzed by Eberline Services using a gas-flow proportional alpha-particle counting system following digestion of the solid sample and co-precipitation of barium and lead sulfate (U.S. Environmental Protection Agency, 2010).

\section{Water Sample Collection}

Water samples were collected in Muleshoe Creek at three locations along the stream reach surrounding the abandoned mining area. Point-grab samples from the center of the stream were collected starting downstream of the mining area and moving upstream to avoid contamination from stream disturbance. Discharge measurements were made at each sample site using a Pygmy meter (Price Pygmy meter no. 227656). Field water-quality parameters, including $\mathrm{pH}$, specific conductance, temperature, dissolved oxygen, and oxidation reduction potential were measured using an In-Situ, Inc. Troll ® 9500 (table 2). Water samples were collected following the traceelement protocol defined by U.S. Geological Survey (2006). Samples were sent to the USGS National Water Quality Laboratory (NWQL) for major- and trace-element analyses.

\section{Results}

\section{Solid-Phase Trace-Element Concentrations}

All uranium waste dump, background, and stream sediment samples were analyzed for total digestible metal concentrations (table 3, located on page 22 in the back of the report). Trace-element concentrations in solid-phase samples collected at mine sites and in ephemeral stream channels downstream of mine sites were compared to trace-element concentrations

Table 2. Field parameters measured in Muleshoe Creek on August 13, 2008, Browns Hole, Utah.

[Abbreviations: DD.dddd, Degrees.decimal degrees; ft, feet; $\mathrm{ft}^{3} / \mathrm{sec}$, cubic feet per second; hh:mm, hour:minute; MDT, Mountain Daylight Time; mg/L, milligrams per liter; mmHg, millimeters of mercury; $\mathrm{mV}$, millivolts; Site ID, site identification; ${ }^{\circ} \mathrm{C}$, degrees Celsius; $\mu \mathrm{S} / \mathrm{cm}$, microsiemens per centimeter at 25 degrees Celsius]

\begin{tabular}{|c|c|c|c|c|c|c|c|c|}
\hline Site ID & Map ID & USGS site number & $\begin{array}{c}\text { Time } \\
\text { (MDT) } \\
\text { (hh:mm) }\end{array}$ & $\begin{array}{l}\text { Latitude } \\
\text { (DD.dddd) }\end{array}$ & $\begin{array}{l}\text { Longitude } \\
\text { (DD.dddd) }\end{array}$ & $\begin{array}{l}\text { Elevation } \\
\quad(\mathrm{ft})\end{array}$ & $\begin{array}{c}\text { Discharge } \\
\left(\mathrm{ft}^{3} / \mathrm{sec}\right)\end{array}$ & $\begin{array}{c}\mathrm{pH} \\
\text { (standard } \\
\text { units) }\end{array}$ \\
\hline $\begin{array}{c}\text { Muleshoe Creek } 1 \\
\text { downstream }\end{array}$ & Muleshoe-1 & 382048109230801 & $10: 00$ & 38.34677 & 109.38558 & 5,680 & 0.27 & 8.3 \\
\hline $\begin{array}{l}\text { Muleshoe Creek } 2 \\
\text { at mining area }\end{array}$ & Muleshoe-2 & 382046109225801 & $11: 15$ & 38.34607 & 109.38286 & 5,720 & 0.27 & 8.4 \\
\hline
\end{tabular}

\begin{tabular}{|c|c|c|c|c|c|c|c|}
\hline Site ID & Map ID & USGS site number & 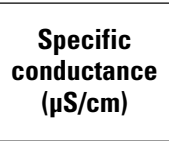 & $\begin{array}{c}\text { Temperature } \\
\left({ }^{\circ} \mathrm{C}\right)\end{array}$ & $\begin{array}{c}\text { Dissolved } \\
\text { oxygen } \\
\text { (mg/L) }\end{array}$ & $\begin{array}{c}\text { Barometric } \\
\text { pressure } \\
\text { (mmHg) }\end{array}$ & $\begin{array}{c}\text { Oxidation } \\
\text { reduction } \\
\text { potential } \\
(\mathrm{mV})\end{array}$ \\
\hline $\begin{array}{l}\text { Muleshoe Creek } \\
2 \text { at mining area }\end{array}$ & Muleshoe-2 & 382046109225801 & 946 & 16.4 & 9.17 & 621 & +27 \\
\hline
\end{tabular}


in solid-phase samples collected at undisturbed background sites within the study area (fig. 9). The median value of seven background samples collected from various locations in the Browns Hole study area (fig. 2) determined the background concentration for all trace elements. All sites exceeded background concentrations for arsenic, radium, uranium, and vanadium. Concentrations of arsenic at BH-35 ranged from background levels of 5 parts per million (ppm) up to 195 ppm. Concentrations of radium ranged from background levels of $1.39 \mathrm{pCi} / \mathrm{g}$ up to $91 \mathrm{pCi} / \mathrm{g}$ at BH-30. Concentrations of uranium ranged from background levels of $6.2 \mathrm{ppm}$ up to 359 $\mathrm{ppm}$ at BH-46. Concentrations of vanadium ranged from background levels of $70 \mathrm{ppm}$ up to 2,550 ppm at BH-30. Many

Antimony (Sb)
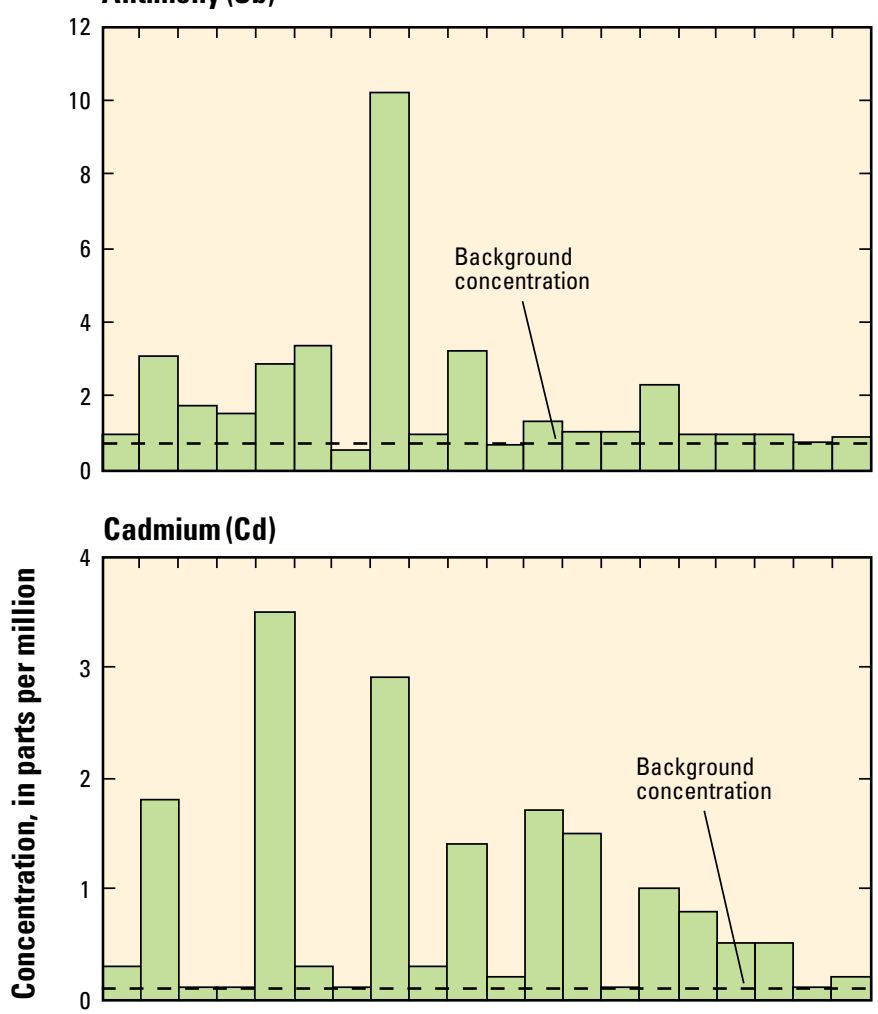

Chromium(Cr)

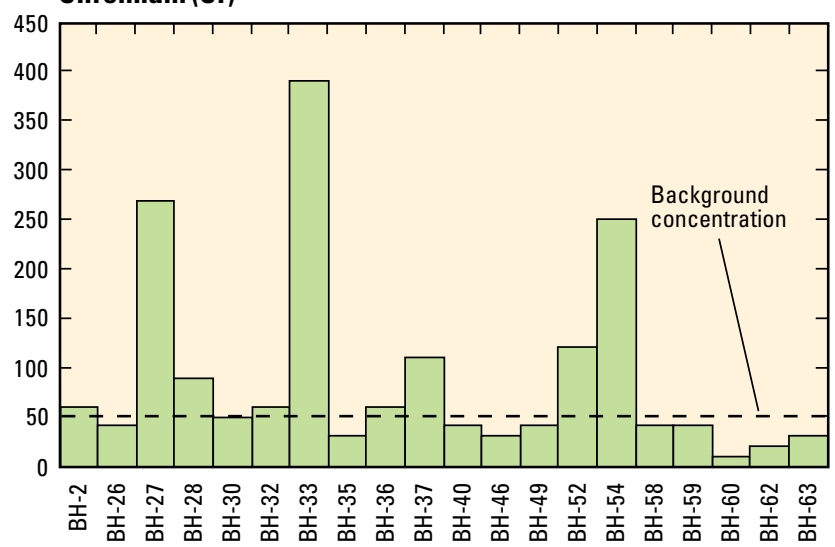

sites also exceeded background concentrations for cadmium, cobalt, chromium, copper, molybdenum, lead, antimony, tungsten, and zinc (fig. 9). Concentrations of cadmium ranged from background levels of $0.1 \mathrm{ppm}$ up to $3.5 \mathrm{ppm}$ at BH-30. Concentrations of cobalt ranged from background levels of 10 ppm to $90 \mathrm{ppm}$ at BH-27. Concentrations of chromium ranged from background levels of $50 \mathrm{ppm}$ up to $390 \mathrm{ppm}$ at BH-33. Concentrations of copper ranged from background levels of $20 \mathrm{ppm}$ up to $110 \mathrm{ppm}$ at $\mathrm{BH}-27$. Concentrations of molybdenum ranged from background levels of $10 \mathrm{ppm}$ up to $90 \mathrm{ppm}$ at $\mathrm{BH}-27$. Concentrations of lead ranged from background levels of $14.6 \mathrm{ppm}$ up to $266 \mathrm{ppm}$ at BH-35. Concentrations of antimony ranged from background levels of $0.69 \mathrm{ppm}$ up
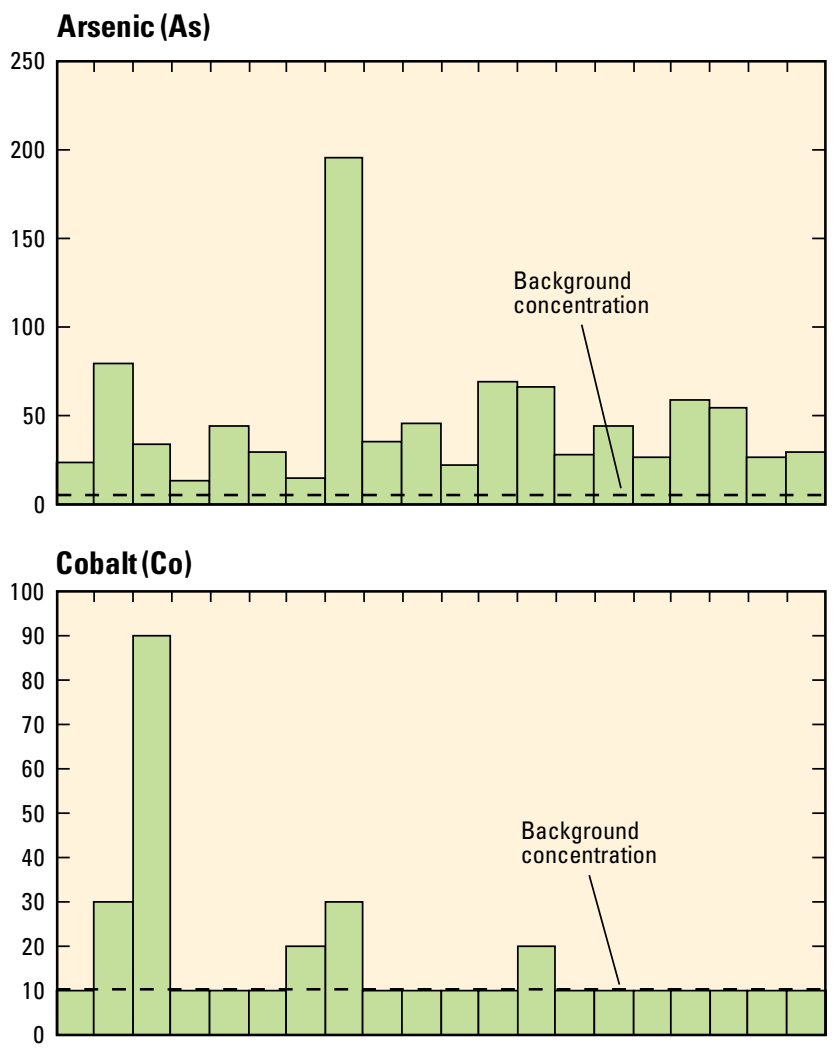

Copper (Cu)

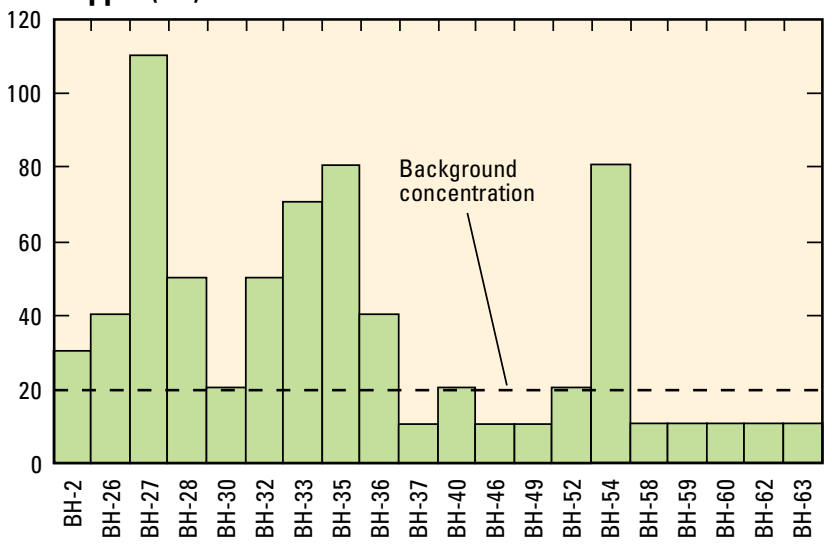

Figure 9. Concentrations of selected trace elements in solid-phase material from 20 uranium mine waste dump sites in Browns Hole, Utah. Dashed line indicates the median value for undisturbed background samples from seven sites. 
Molybdenum (Mo)
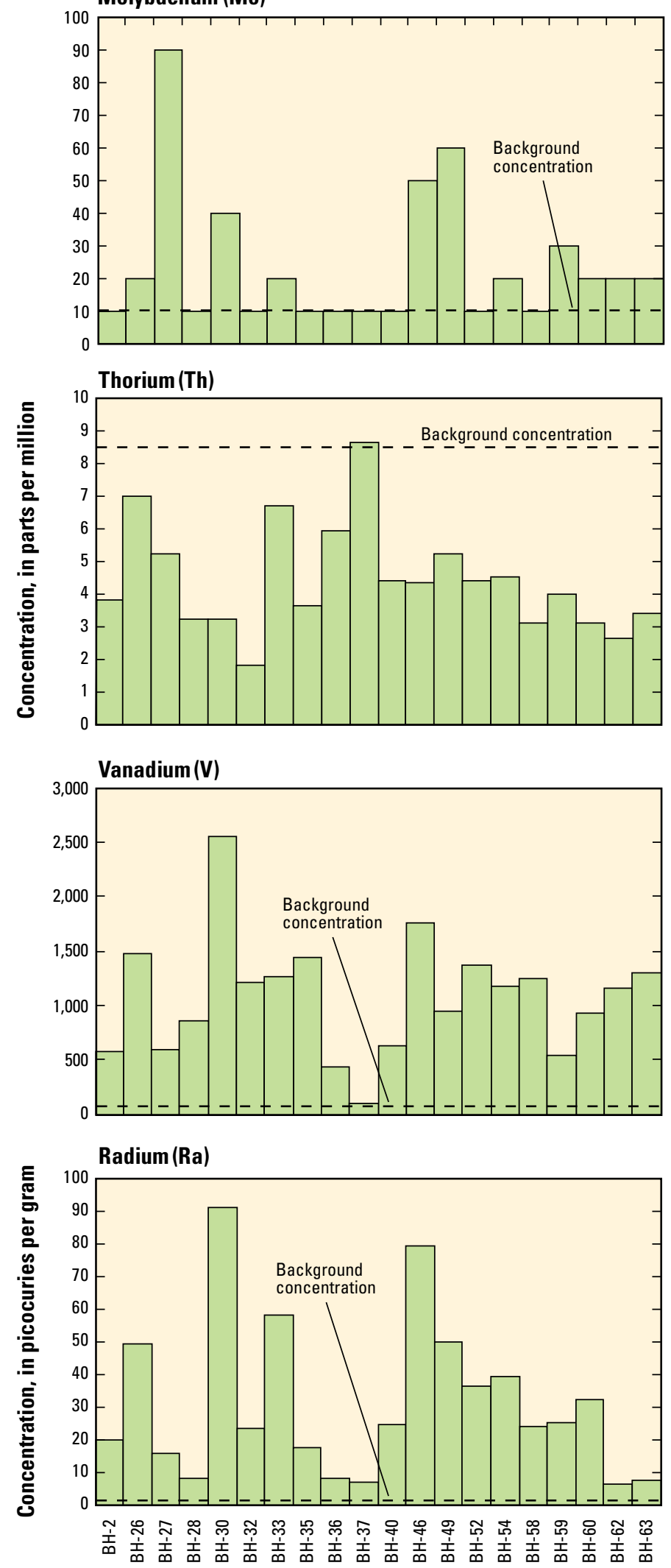

Lead $(\mathbf{P b})$
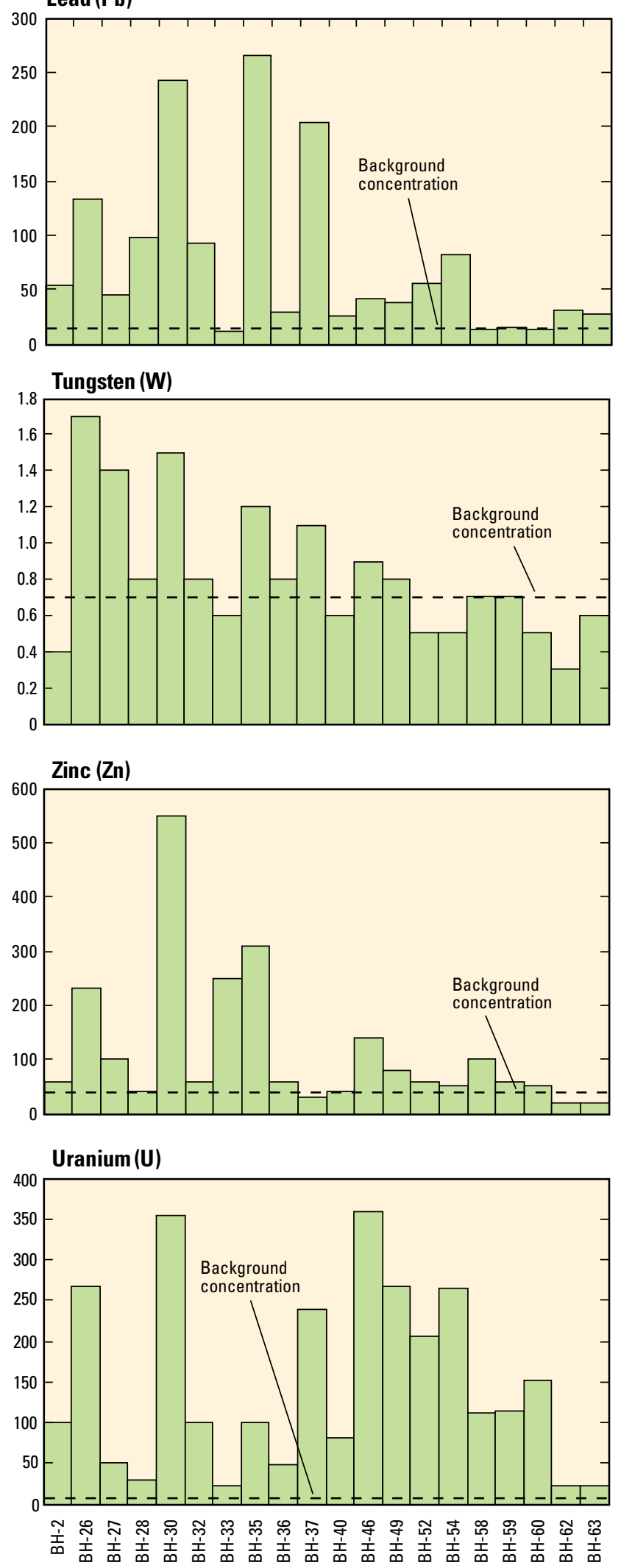

Figure 9. Concentrations of selected trace elements in solid-phase material from 20 uranium mine waste dump sites in Browns Hole, Utah. Dashed line indicates the median value for undisturbed background samples from seven sites.-Continued 
to $3.38 \mathrm{ppm}$ at $\mathrm{BH}-32$. Concentrations of tungsten ranged from background levels of $0.7 \mathrm{ppm}$ up to $1.7 \mathrm{ppm}$ at BH-26. Concentrations of zinc ranged from background levels of 40 ppm up to $550 \mathrm{ppm}$ at BH-30. Only one site, BH-37, exceeded background concentrations for thorium. Overall, the highest concentrations of the selected trace elements occurred at BH-30 and BH-46, which were also the sites that had the highest concentrations of radium and uranium.

Analytical results for sediment samples collected from dry ephemeral stream channels downstream of mine sites BH-36, $\mathrm{BH}-40$, and $\mathrm{BH}-49$ were used to plot transects of radium, uranium, vanadium, and arsenic concentrations at various distances from the mine sites (fig. 10). For all three sites, the concentrations of radium, uranium, vanadium, and arsenic in sediment from downstream were significantly lower than the concentrations found in samples from the mine sites. Downstream samples, BH-36-SED and BH-49-SED1, 2, 3, 4, and 5 , all yielded concentrations of radium and uranium that were above background concentrations. Ephemeral stream sediment samples downstream from BH-49 yielded a noticeable decrease in concentrations of radium, uranium, and vanadium with increasing distance from the source material. Similar decreases in concentration with increasing distance from the source material were observed for vanadium and arsenic. One ephemeral stream site located $45 \mathrm{ft}$ downstream of BH-36, BH-36-SED, yielded elevated radium concentrations relative to background. BH-40-SED1 and 2 yielded concentrations that were near background for radium, uranium, vanadium, and arsenic and had no significant decrease in concentrations with increasing distance from the source material.

\section{Stream-Water Trace-Element Concentrations}

Trace-element concentrations in the water samples collected in Muleshoe Creek were compared to water-quality standards for aquatic life (U.S. Environmental Protection Agency, 2007b) and drinking water (U.S. Environmental Protection Agency, 2007a; table 4). For constituents without a water-quality standard for aquatic life or drinking water, no comparison was made. At all three sample collection sites (fig. 2), 1,200 ft upstream of BH-40 (Muleshoe-3), at the mining area (Muleshoe-2), and 1,000 ft downstream of BH-40 (Muleshoe-1), no elements exceeded the water-quality standards (tables 5 and 6). Uranium concentration increased slightly from upstream to downstream samples, with a concentration of $4.4 \mu \mathrm{g} / \mathrm{L}$ upstream of BH- $40,5.62 \mu \mathrm{g} / \mathrm{L}$ at BH-40, and $5.96 \mu \mathrm{g} / \mathrm{L}$ downstream of BH-40 (table 6). Arsenic concentration increased slightly from upstream to downstream samples, with a concentration of $1.3 \mu \mathrm{g} / \mathrm{L}$ upstream of BH-40, $1.5 \mu \mathrm{g} / \mathrm{L}$ at BH-40, and $1.8 \mu \mathrm{g} / \mathrm{L}$ downstream of BH-40 (table 6). Concentrations of aluminum, antimony, barium, beryllium, cadmium, chromium, copper, iron, lead, magnesium, manganese, molybdenum, nickel, radium, selenium, silver, sodium, vanadium, and zinc remained relatively stable or decreased from upstream to downstream samples (tables 5 and 6).
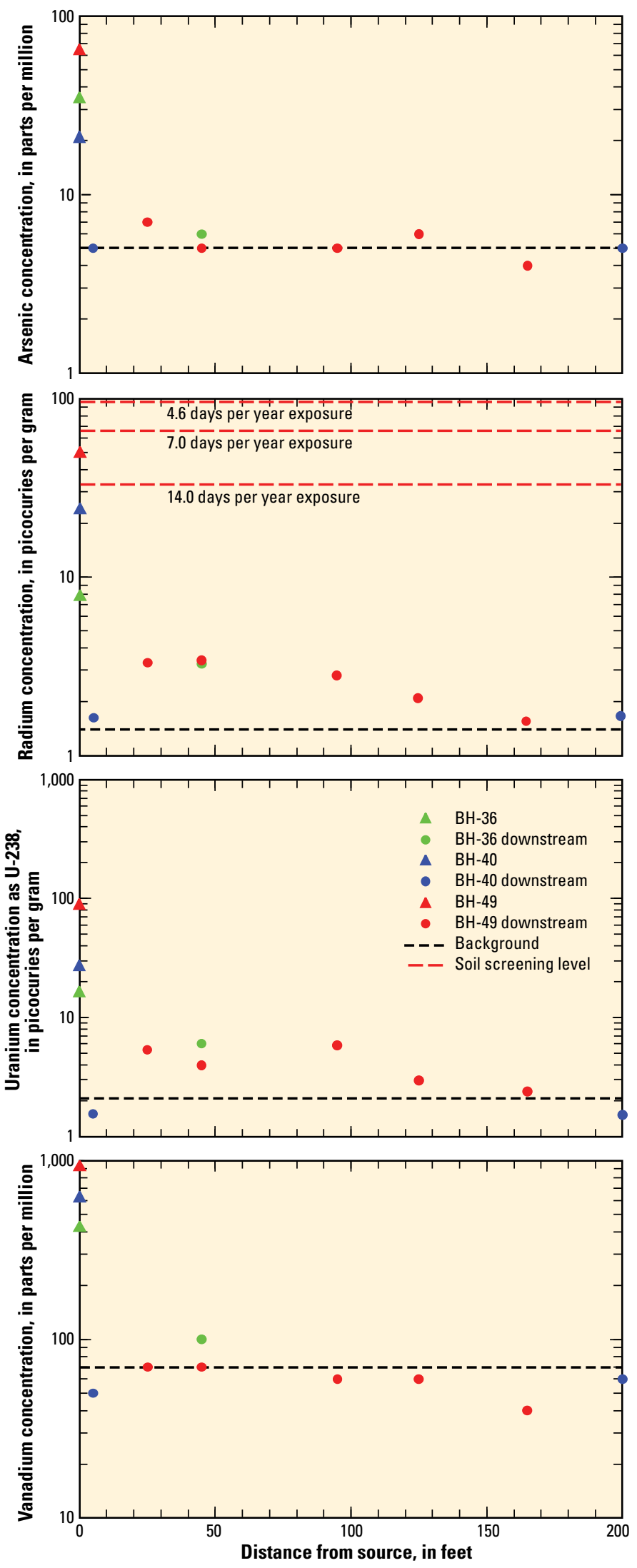

Figure 10. Solid-phase sediment transects of BH-36, BH-40, and $\mathrm{BH}-49$ and associated downstream streambed sediment for total radium, uranium, vanadium, and arsenic concentrations. 
Table 4. U.S. Environmental Protection Agency drinking waterquality standards' and aquatic life water-quality standards².

[Abbreviations: na, not applicable; $\mathrm{pCi} / \mathrm{L}$, picocuries per liter; $\mu \mathrm{g} / \mathrm{L}$, micrograms per liter]

\begin{tabular}{|c|c|c|}
\hline Element & $\begin{array}{c}\text { Drinking- } \\
\text { water-quality standard } \\
\text { concentration }(\mu \mathrm{g} / \mathrm{L})\end{array}$ & $\begin{array}{c}\text { Aquatic life } \\
\text { water-quality standard } \\
\text { concentration }(\mu \mathrm{g} / \mathrm{L})\end{array}$ \\
\hline Antimony (Sb) & 6 & na \\
\hline Arsenic (As) & 10 & 150 \\
\hline Barium (Ba) & 2,000 & na \\
\hline Beryllium (Be) & 4 & na \\
\hline Cadmium (Cd) & 5 & 0.25 \\
\hline Chromium (Cr) & 100 & na \\
\hline Cobalt (Co) & na & na \\
\hline Copper (Cu) & 1,300 & 9 \\
\hline Iron (Fe) & 300 & na \\
\hline Lead (Pb) & 15 & 2.5 \\
\hline Manganese (Mn) & 50 & na \\
\hline Mercury (Hg) & 2 & 0.77 \\
\hline Molybdenum (Mo) & na & na \\
\hline Nickel (Ni) & na & 52 \\
\hline Radium (Ra) (pCi/L) & 5 & na \\
\hline Selenium (Se) & 50 & 5 \\
\hline Silver (Ag) & 100 & na \\
\hline Thallium (Tl) & 2 & na \\
\hline Uranium (U) & 30 & na \\
\hline Vanadium (V) & na & na \\
\hline Zinc (Zn) & 5,000 & 120 \\
\hline
\end{tabular}

${ }^{1}$ Drinking-water-quality standards (U.S. Environmental Protection Agency, 2007a).

${ }^{2}$ Aquatic life water-quality standards (U.S. Environmental Protection Agency, 2007b).

\section{Quality Control}

Two standard reference materials obtained from the USGS (Green River Shale (SGR-1B) and Mica Schist (SDC-1)) were submitted blindly with the routine waste rock and stream sediment samples collected in the Browns Hole study area. Analytical results from the standard reference materials were generally within acceptable limits and were within \pm 12.4 percent for Green River Shale (SGR-1B) and \pm 10.3 percent for Mica Schist (SDC-1) on average (table 3). An onsite field blank for water samples consisting of certified inorganic blank water poured into a sample bottle to replicate the point-grab sampling method yielded results below laboratory reporting levels (tables 5 and 6).

\section{Soil Screening Levels for Radium, Uranium, and Thorium}

Three soil screening levels (SSL) for various exposure durations were determined for the combined carcinogenic effects of radium, uranium, and thorium as radionuclides on the basis of calculations made with RESRAD 6.5, a computer model designed to estimate radiation doses and risks from residual radioactive materials (Yu and others, 1993). Soil screening levels were evaluated for a maximum annual dosage of 15 additional millirem per year (mrem/yr) (U.S. Environmental Protection Agency, 1997a). Several exposure pathways were considered in the model: direct external exposure to contaminated soils, internal exposure to inhaled radionuclides, and internal exposure by ingestion of contaminated soils. RESRAD also considers exposures from ingestion of plants grown in contaminated soils, from ingestion of meat derived from livestock fed with contaminated feed or water, from drinking water directly, and from ingestion of fish from a contaminated body of water. These pathways were not included on the basis of low radionuclide concentrations in background samples and water-quality samples. The waste-rock sites do not support significant plant life and have an average radium concentration of $31 \mathrm{pCi} / \mathrm{g}$, whereas areas adjacent to the piles with significant plant life and potential for livestock forage have an average radium concentration of $1.5 \mathrm{pCi} / \mathrm{g}$. Given that the natural background concentration in the area is less than 5 percent of the average radium concentration found in the waste-rock piles, radionuclide propagation by local plant-life uptake poses a minimal risk to humans. Water-quality samples from Muleshoe Creek yielded concentrations of the radioactive elements uranium, radium, and thorium that were below U.S. Environmental Protection Agency (USEPA) aquatic-life and drinking-water standards, resulting in a minimal risk for consumption of water sources by humans and aquatic life (U.S. Environmental Protection Agency, 2007a, b).

For this study, the radioactive elements uranium, radium, and thorium were analyzed for total concentrations in soil. Both uranium and thorium were reported in ppm, while radium was reported in $\mathrm{pCi} / \mathrm{g}$. Concentrations of both uranium and thorium were converted to activity of uranium-238 and thorium-232 because these are the most abundant isotopes, with 99.27 percent of natural uranium occurring as uranium-238 and 100 percent of natural thorium as thorium-232. Radioactive concentration for total radium was considered equal to the activity of radium-226 because it is the most abundant isotope associated with decay of natural uranium deposits, such as those found at Browns Hole. Natural uranium consists of uranium-234, -235 , and -238 in ratios corresponding to natural isotopic abundances, which are less than $0.01,0.72$, and 99.27 percent, respectively. The uranium decay series considered includes the natural uranium species along with the decay chains of uranium-238, uranium-235, and one daughter product of uranium-234, thorium-230 (fig. 11). Radium-226 and its associated short-lived decay chain along with thorium-232 and its decay chain were considered as separate radionuclide series (fig. 11). Given the three exposure pathways considered, radium-226 and its associated decay chain poses the greatest risk to human health as shown by the model's sensitivity to radium-226 concentrations.

Because of the particular uses of the study area, some of the assumptions about the parameters used by RESRAD have 
Table 5. Chemical analysis of filtered water samples collected on August 13, 2008, from Muleshoe Creek, Browns Hole, Utah.

[Abbreviations: DD.dddd, Degrees.decimal degrees; E, estimated; Site ID, site identification; ft, feet; hh:mm, hour:minute; MDT, Mountain Daylight Time; $\mathrm{mg} / \mathrm{L}$, milligrams per liter; $\mu \mathrm{g} / \mathrm{L}$, micrograms per liter; $<$, less than laboratory reporting level; NA, not analyzed]

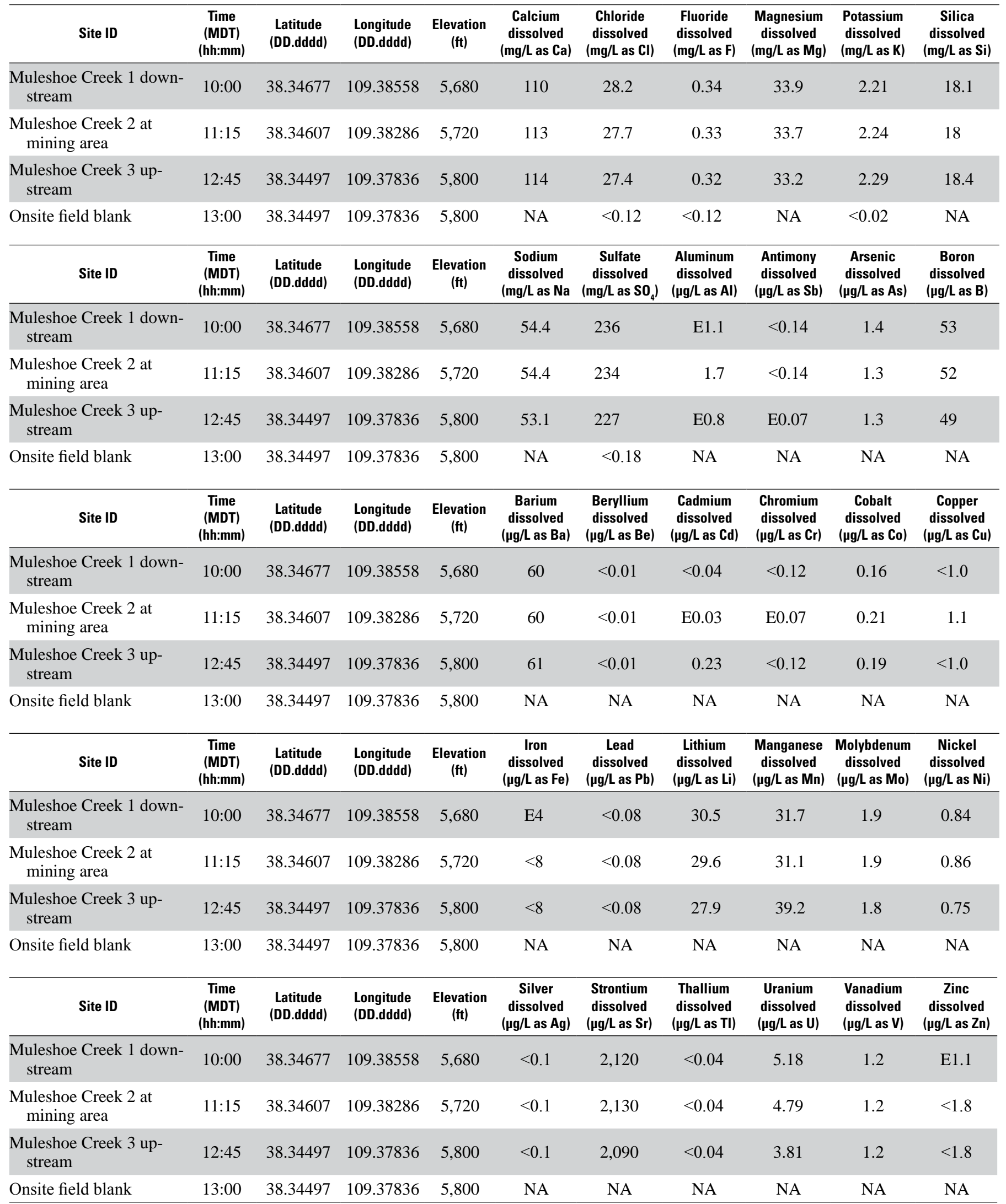


Table 6. Chemical analysis of unfiltered water samples collected on August 13, 2008, from Muleshoe Creek, Browns Hole, Utah.

[Abbreviations: DD.dddd, Degrees.decimal degrees; ft, feet; hh:mm, hour:minute; MDT, Mountain Daylight Time; mg/L, milligrams per liter; pCi/L, picocuries per liter; Site ID, site identification; $\mu \mathrm{g} / \mathrm{L}$, micrograms per liter; $<$, less than laboratory reporting level]

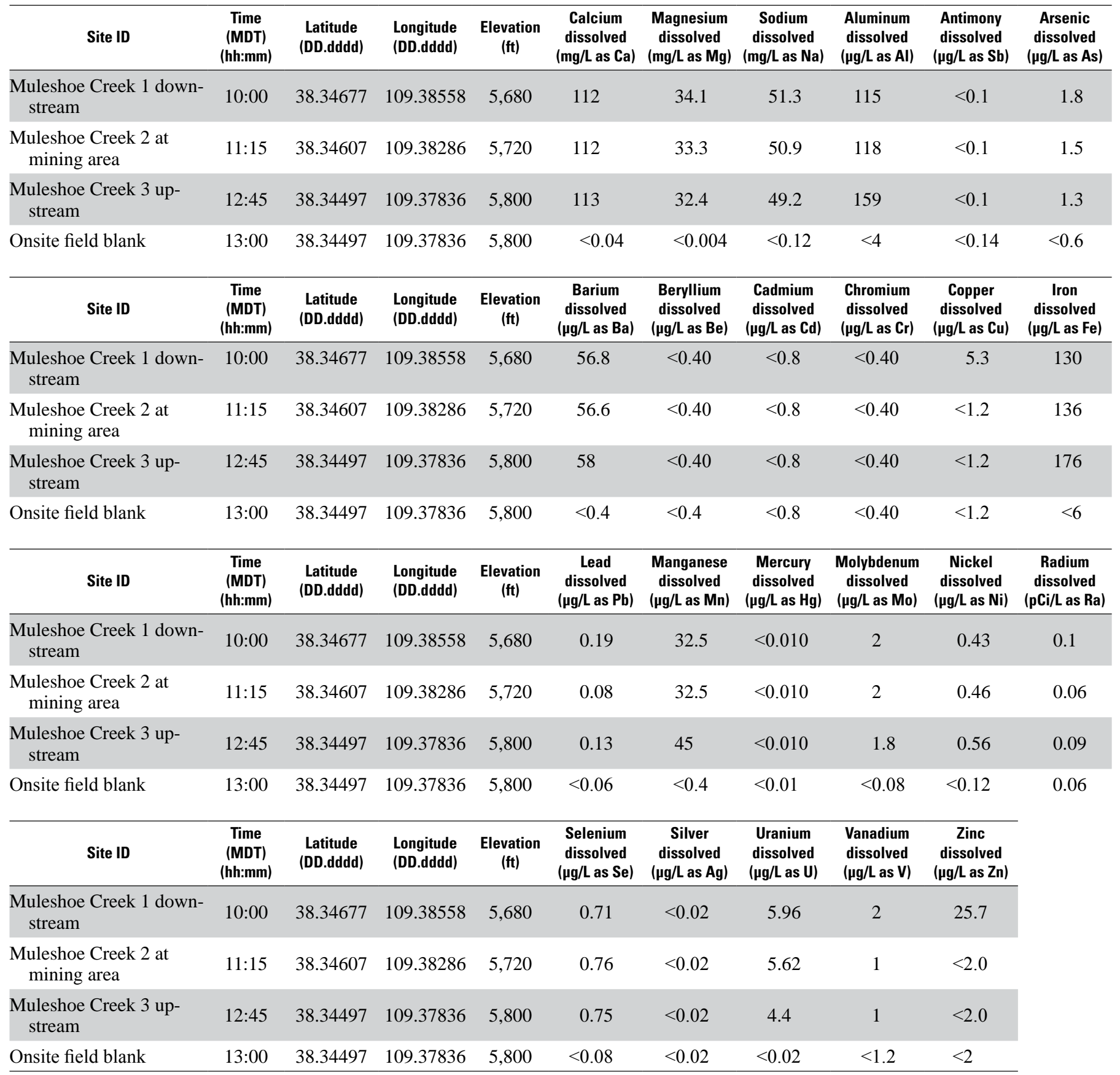




\section{Uranium-235 Series}
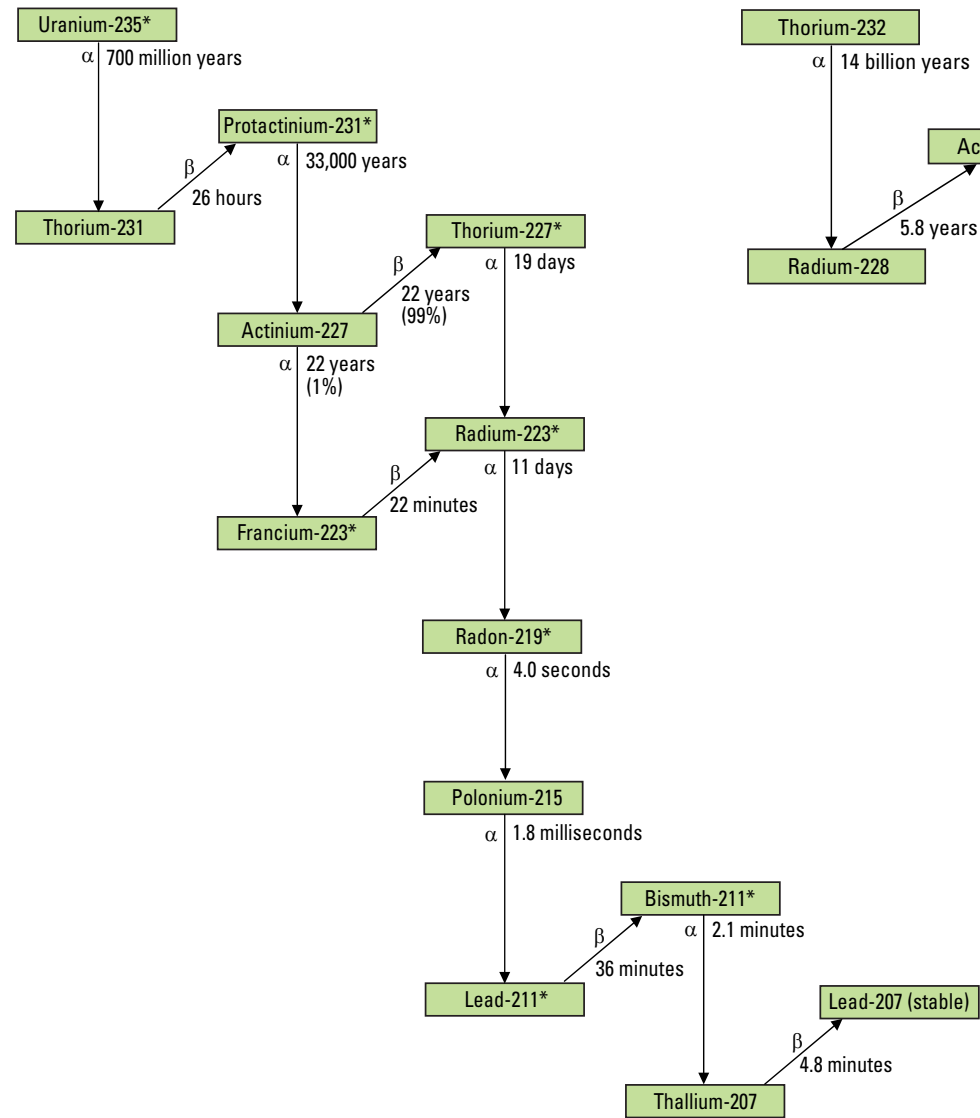

\section{Thorium-232 Series}

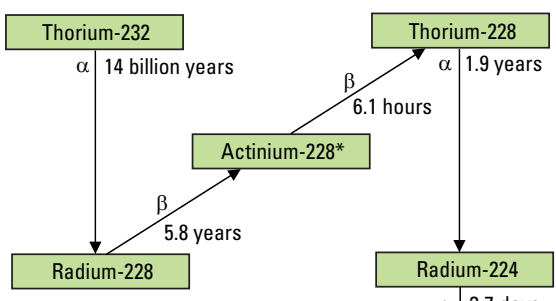

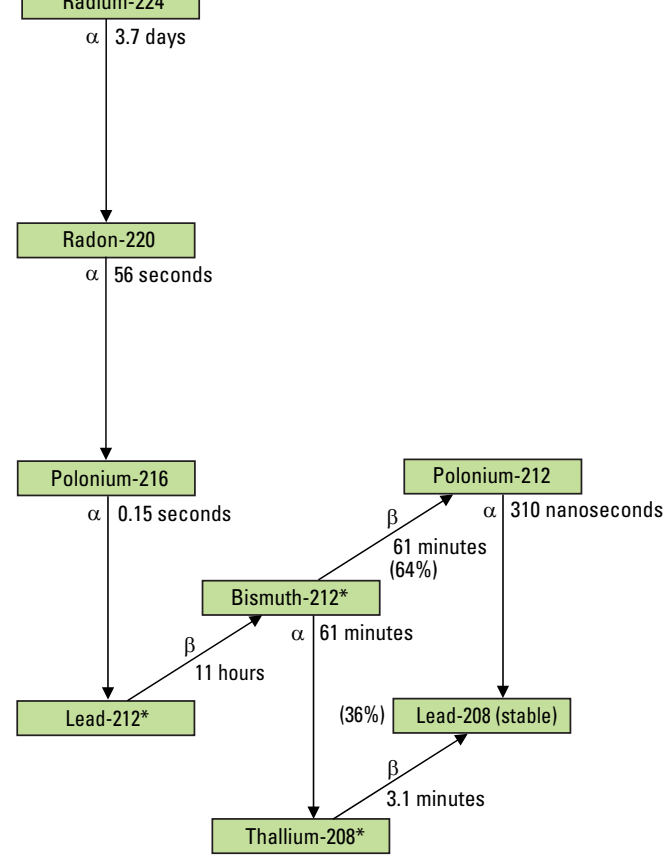

Uranium-238 Series

Radium-226 Series

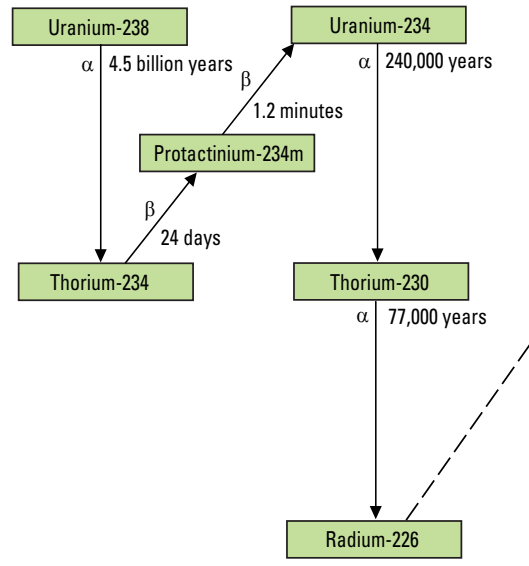

Padium-226 
been altered to fit the site conditions. The primary use of the area appears to be for recreational off-road activity by riders of all-terrain vehicles (ATVs), on the basis of visual inspection during sample collection. Two primary use scenarios were considered in determining the amount of annual exposure a visitor experiences. The first scenario considers the duration of activities of an individual that lives in proximity to the site and visits the site periodically during any given year. The total annual visitation by an individual to the site was 4.6 days per year based on calculations made for daily duration of outdoor activities by a young adult (U.S. Environmental Protection Agency, 1997b, table 15.3). The second scenario considers the duration of time spent on the site by an individual who is using the area as a recreation destination and spends 7 to 14 days on the site, the latter equal to the maximum annual recreational occupancy of a site by the BLM. In all scenarios, RESRAD was set up to inspect three exposure pathways appropriate to the usage scenarios that were identified: (a) external gamma exposure, (b) inhalation exposure, and (c) soil ingestion exposure. Soil screening levels were determined with respect to the concentration of radium, with all other uranium decay series radionuclides set to secular equilibrium with radium-226. In the Colorado Plateau region uranium deposits, secular equilibrium between radium and uranium is typically not observed, and in many cases, uranium deposits are depleted in radium with respect to uranium by a process of leaching daughter products from primary uranium minerals by formation of secondary minerals due to changing groundwater conditions and oxidation (Stearn and Stieff, 1959). Modifications to default data used by RESRAD to calculate an annual radiation dosage were made in the "Occupancy and Ingestion: Dietary" subsections of modifiable data; in all other sub-sections, default data were used (Yu and others, 1993). In the "Occupancy" sub-section, an inhalation rate of $14,016 \mathrm{~m}^{3} / \mathrm{yr}$ was used over the default value of $8,400 \mathrm{~m}^{3} / \mathrm{yr}$ to reflect moderate activities by an individual either riding an ATV or involved in outdoor activities (U.S. Environmental Protection Agency, 1997b, table 5.23.) The mass loading for inhalation was set to 0.0004 $\mathrm{g} / \mathrm{m}^{3}$ over the default value $0.0001 \mathrm{~g} / \mathrm{m}^{3}$ to reflect the increased dust present on unpaved roads while ATVs are in use (Yu and others, 1993 Chapter 35). The indoor time fraction was set to 0.0 over the default of 0.5 , implying that the individual spends the entire time on the site outdoors. The outdoor time fraction was set to the annual exposure duration that was considered appropriate: 0.013 for 4.6 days per year, 0.019 for 7.0 days per year, and 0.038 for 14.0 days per year. Outdoor time fractions are expressed as fractions of a 1-year period. In the "Ingestion: Dietary" sub-section, a soil ingestion rate of 73 grams per year ( $\mathrm{g} / \mathrm{yr}$ ) was used over the default value of $36.5 \mathrm{~g} / \mathrm{yr}$ to represent an average rate for all human age groups, not just adults (U.S. Environmental Protection Agency, 1997b, table 4.23). The resulting SSLs for combined radium, uranium, and thorium for a maximum of 15 additional mrem/yr are $96 \mathrm{pCi} / \mathrm{g}$ radium for 4.6 days per year, $66 \mathrm{pCi} / \mathrm{g}$ radium for 7.0 days per year, and $33 \mathrm{pCi} / \mathrm{g}$ radium for 14.0 days per year.

No samples from the uranium waste dumps exceeded the 4.6 days per year SSL for radium, although BH-30 approached this value with a concentration of $91 \mathrm{pCi} / \mathrm{g}$. Two sites, BH-30 and $\mathrm{BH}-46$, exceeded the 7.0 days per year SSL for radium, with concentrations of $91 \mathrm{pCi} / \mathrm{g}$ and $79 \mathrm{pCi} / \mathrm{g}$, respectively. Seven sites, BH-26, BH-30, BH-33, BH-46, BH-49, BH-52, and $\mathrm{BH}-54$, exceeded the 14.0 days per year SSL for radium, with concentrations of $49 \mathrm{pCi} / \mathrm{g}, 91 \mathrm{pCi} / \mathrm{g}, 58 \mathrm{pCi} / \mathrm{g}, 79 \mathrm{pCi} / \mathrm{g}$, $50 \mathrm{pCi} / \mathrm{g}, 36 \mathrm{pCi} / \mathrm{g}$, and $39 \mathrm{pCi} / \mathrm{g}$, respectively (fig. 12 ). Sediment samples from ephemeral streams downstream from BH-36 and BH-49 showed radium concentrations elevated above local background concentrations for the sites closer to waste piles, but no streambed sites exceeded the SSLs (table 3).

\section{Vulnerability of Waste Dumps to Large-Scale Flood Events}

Periodic rainfall events may fill ephemeral drainages with water and transport some of the waste dump material off site. As a result of the episodic nature of streamflow in the Browns Hole area, no permanent gaging stations are currently recording flow. A set of multiple-linear regression equations have been developed for the state of Utah to estimate peak flows in ungaged drainages. All uranium waste dump sites in Browns Hole are located within Region 6, for which regression equations for 2-, 100-, and 500-year recurrence interval peak flows are given below (Kenney and others, 2007):

$$
\begin{gathered}
\text { PK2 }+4,150 \text { DRNAREA }{ }^{0.553}(\text { ELEV/1,000 })^{-2.45} \\
\text { PK100 }=115,000 \text { DRNAREA }^{0.391}(\text { ELEV } / 1,000)^{-2.58} \\
\text { PK100 }=258,000 \text { DRNAREA }^{0.344}(\text { ELEV/1,000 })^{-2.65}
\end{gathered}
$$

where

PK is the peak flow, and the number following PK represents the recurrence interval in years;

DRNAREA is the drainage area in square miles; and ELEV is the mean basin elevation in feet.

The parameters and equations for drainage areas in many states, including Utah, were made into an interactive website, StreamStats (Ries III and others, 2004). All Browns Hole sample site locations were input into the StreamStats website to determine the drainage basin characteristics contributing to runoff at the uranium waste dump sites (table 7). Of the sites in Browns Hole, only two waste dumps had significant associated drainage basin areas, $\mathrm{BH}-27$ and $\mathrm{BH}-36$. Drainage basin areas for $\mathrm{BH}-27$ and $\mathrm{BH}-36$ were 0.13 and $0.12 \mathrm{mi}^{2}$, respectively. Also, two stream sediment sites leading away from waste dump BH-40 were associated with the large 16.2 $\mathrm{mi}^{2}$ drainage basin area of Muleshoe Creek.

Valid ranges for area and mean basin elevation in equations $1-3$ are $0.87-532 \mathrm{mi}^{2}$ and $4,300-9,380 \mathrm{ft}$, respectively. Many drainage area values were less than the minimum value of $0.87 \mathrm{mi}^{2}$, but all mean basin elevation values fell within the valid range (table 7). Peak flows estimated from values outside 


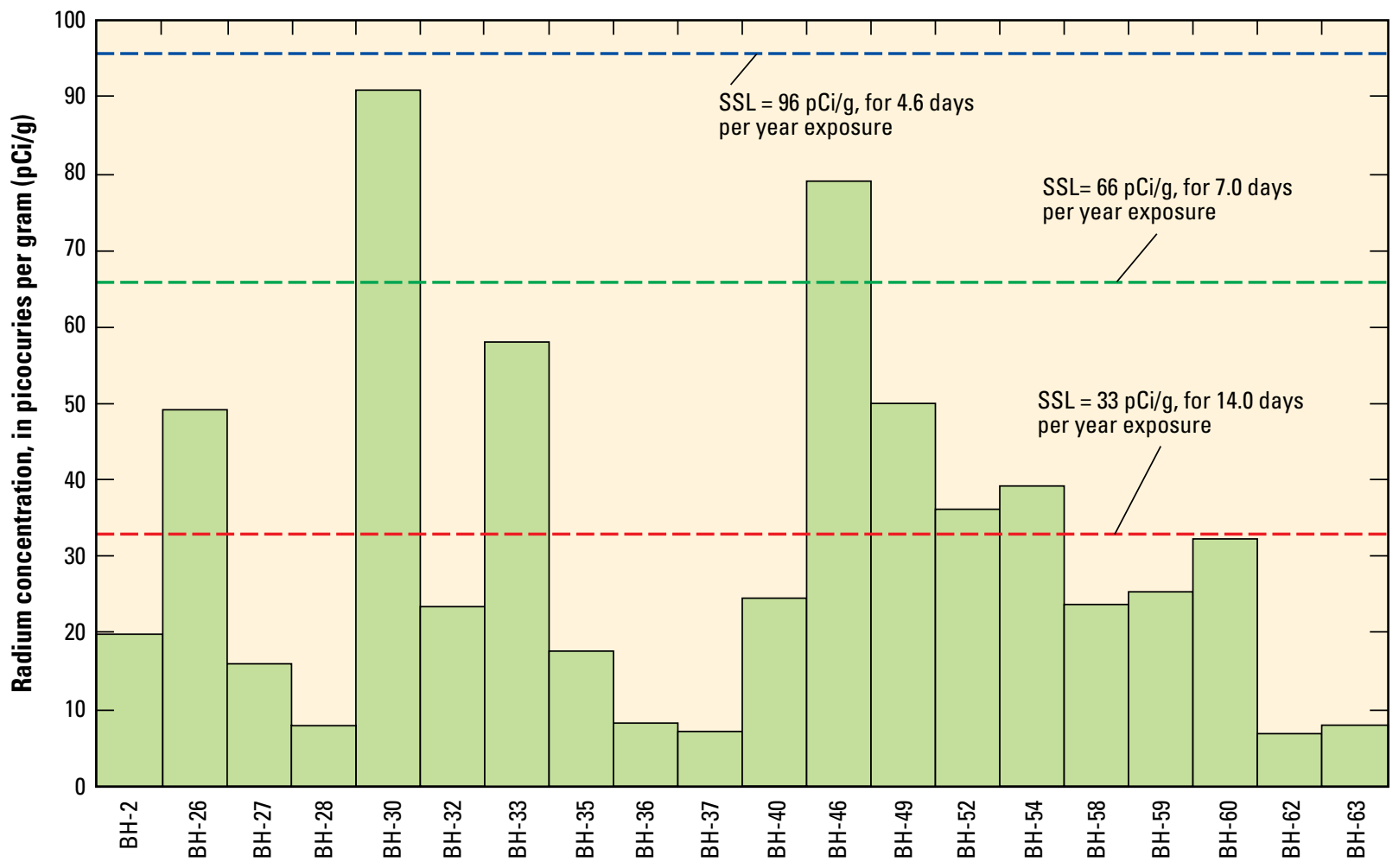

Figure 12. Concentration of radium from 20 waste dump samples collected from Browns Hole, Utah. Colored dashed lines indicate various soil screening levels (SSL) for three exposure durations.

of valid regression equation ranges are extrapolations with unknown errors. The errors given for values within the valid range for PK2, PK100, and PK500 are 110, 61, and 66 percent average standard error of prediction, respectively (Kenney and others, 2007).

Uranium waste dumps with significant drainage basins, BH-27, BH-36, and portions of areas associated with BH-40, have a higher potential to be affected by flood events than other sites in the study area. BH-27 is located in a flow path within a drainage that can produce streamflow discharges of $16.4,500$, and $1,090 \mathrm{ft}^{3} / \mathrm{s}$ for peak flow recurrence intervals of 2,100 , and 500 years, respectively. BH-36 is located in a flow path within a drainage that can produce streamflow discharges of $15.6,481$, and $1,050 \mathrm{ft}^{3} / \mathrm{s}$ for peak flow recurrence intervals of 2, 100, and 500 years, respectively. BH-40 is located in proximity to Muleshoe Creek which has a large drainage basin upstream of BH-40 equal to $16.2 \mathrm{mi}^{2}$. BH-40-SED1 and 2 are included in the flow path of Muleshoe Creek when at flood stage, which equates to $158,2,160$, and $3,700 \mathrm{ft}^{3} / \mathrm{s}$ for peak flow recurrence intervals of 2, 100, and 500 years, respectively.

\section{Summary}

Annual exposure times in the Browns Hole study area for 4.6, 7.0, and 14.0 days result in 0,2 , and 7 sites, respectively, that exceeded the soil screening level (SSL) for combined radium, uranium, and thorium via external exposure, inhalation, and soil ingestion. The following sites exceeded one or more of the SSLs: BH-26, BH-30, BH-33, BH-46, BH-49, BH-52, and BH-54.

One site, BH-30 had an elevated radium concentration (91 pCi/g) that approaches the highest SSL for 4.6 days per year. Increased concentrations of radium, uranium, vanadium, and arsenic relative to background in downstream ephemeral streams suggest that transport of abandoned mine dump material is occurring. At two sites, $\mathrm{BH}-27$ and $\mathrm{BH}-36$, which lie directly adjacent to flow paths of stream channels, sediment from waste-rock piles has a high potential to become mobilized and transported significant distances by peak flow events that have recurrence intervals of 2, 100, and 500 years. Although results from StreamStats suggest that the large waste dump associated with BH-40 has a small drainage basin, it lies in proximity to the perennial stream, Muleshoe Creek. Given the magnitude of potential discharge of Muleshoe Creek associated with peak flow events on 2-, 100-, and 500-year recurrence intervals, material from $\mathrm{BH}-40$ also has a high potential to become mobilized and transported by peak flow events. 
Table 7. Drainage area characteristics associated with uranium waste dump samples, Browns Hole, Utah.

[Abbreviations: DD.dddd, Degrees.decimal degrees; $\mathrm{ft}$, feet; $\mathrm{ft}^{3} / \mathrm{sec}$, cubic feet per second; in, inches; $\mathrm{mi}^{2}$, square miles; N/A, not available; Site ID, site identification]

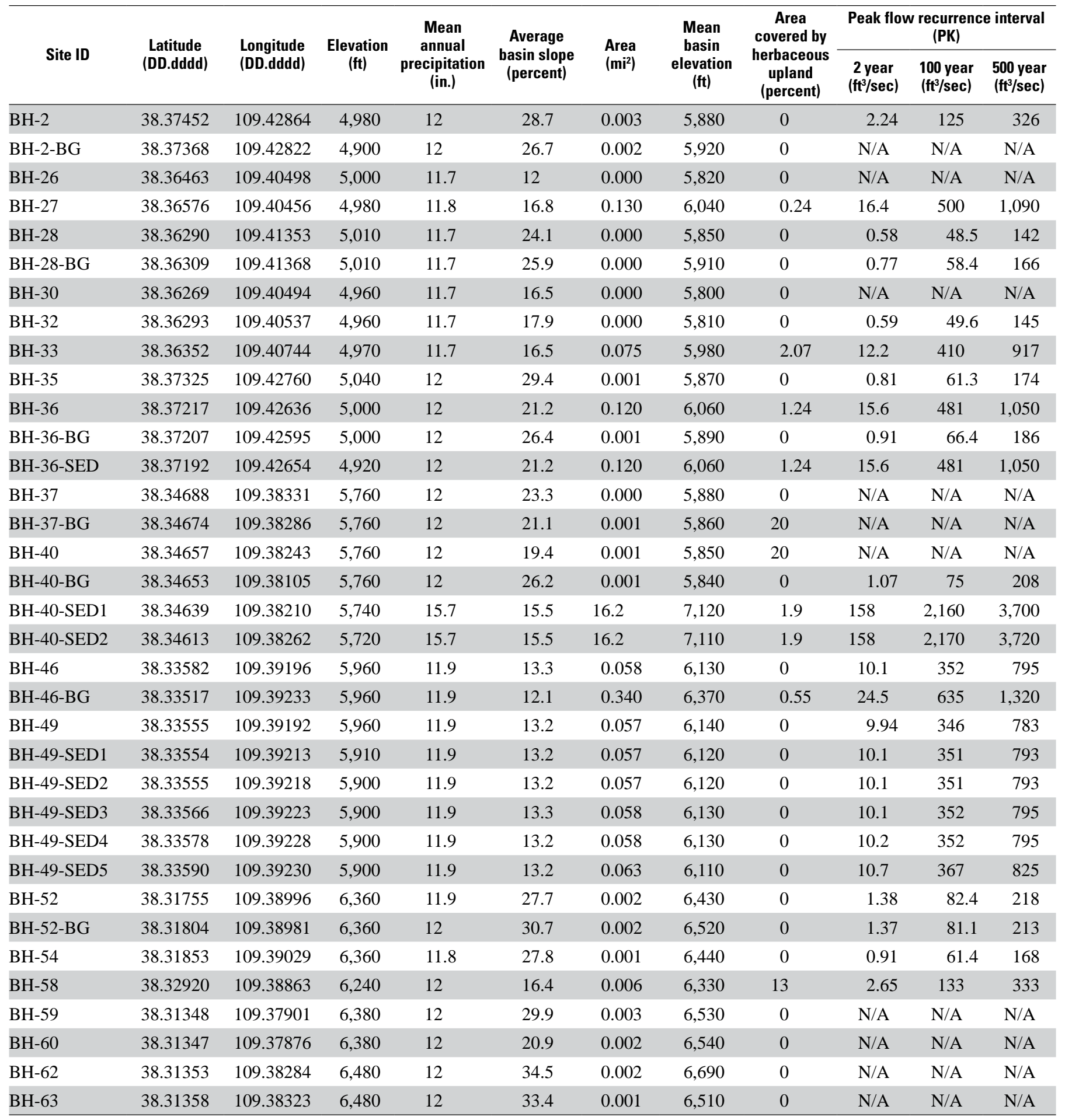




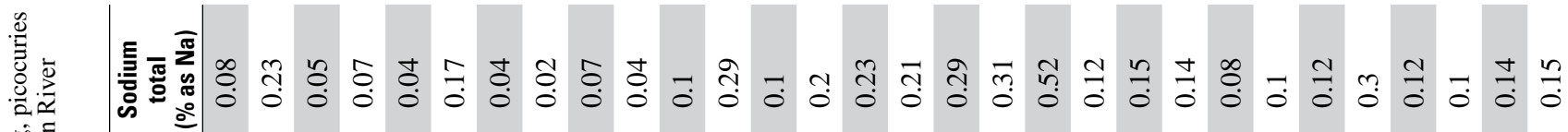

نे.

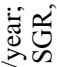

突

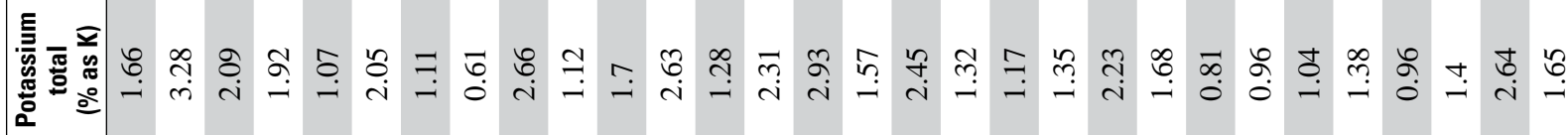

崂

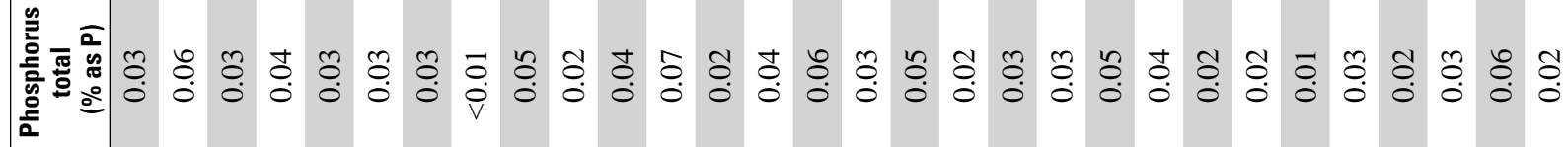

हों

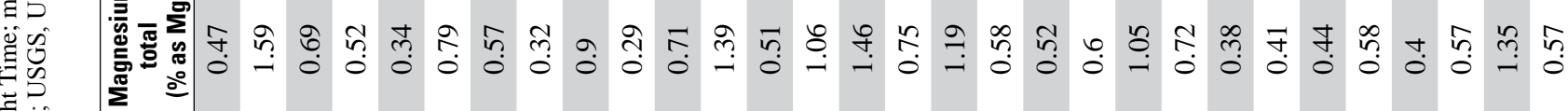

.0.

窎

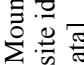

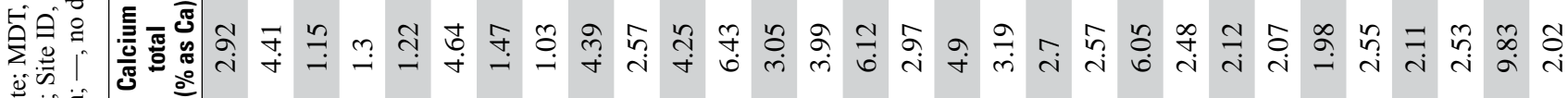

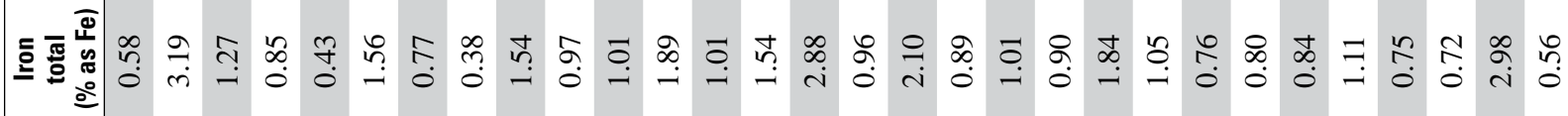

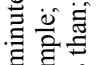

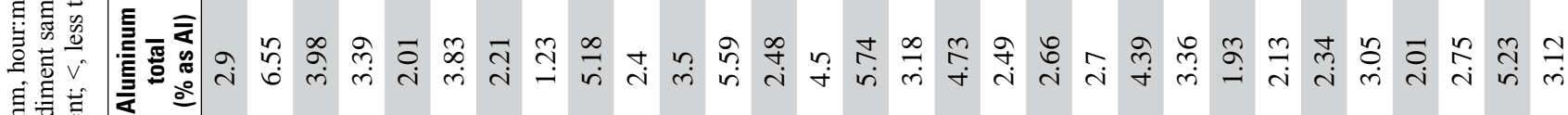

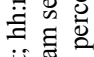

吾焉。

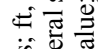

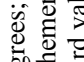

$\stackrel{\pi}{\pi}$

흔

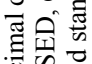

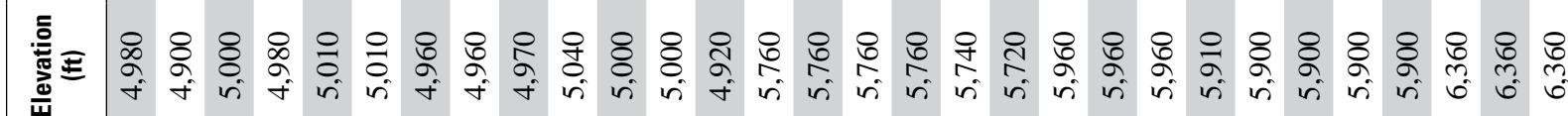

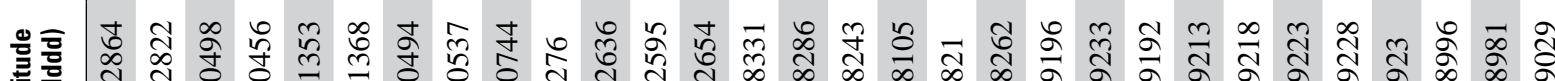

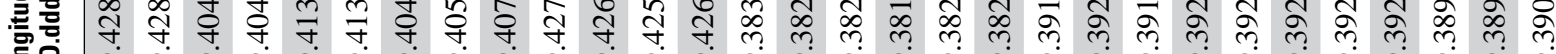

ज它

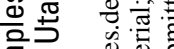

焉 $\frac{0}{0}$

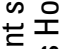

के

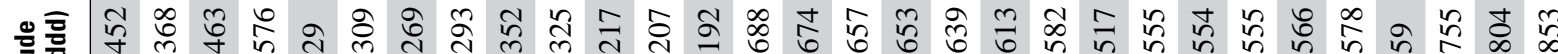

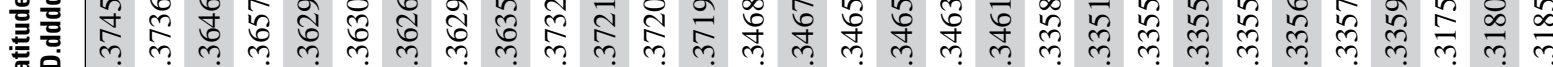

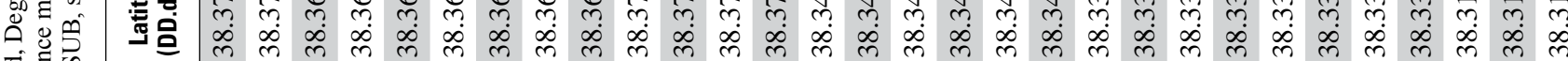

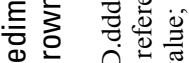

के

突

穴

트릉

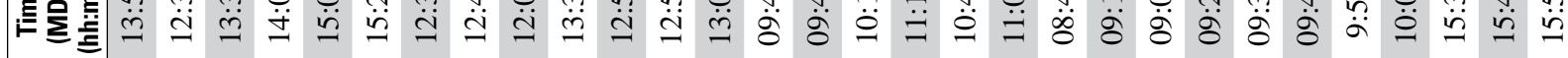

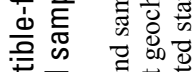

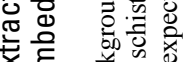

ช

西离

.

I

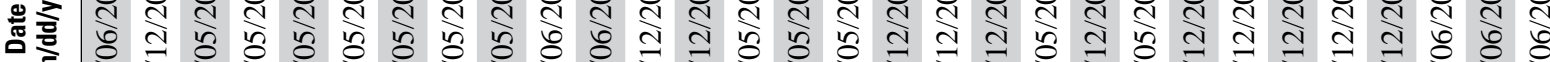

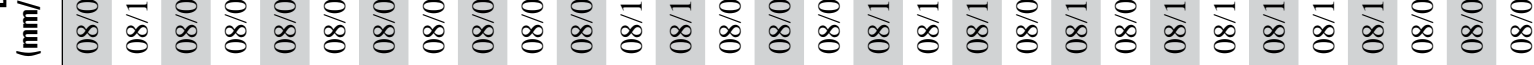

ธ。

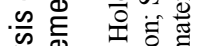

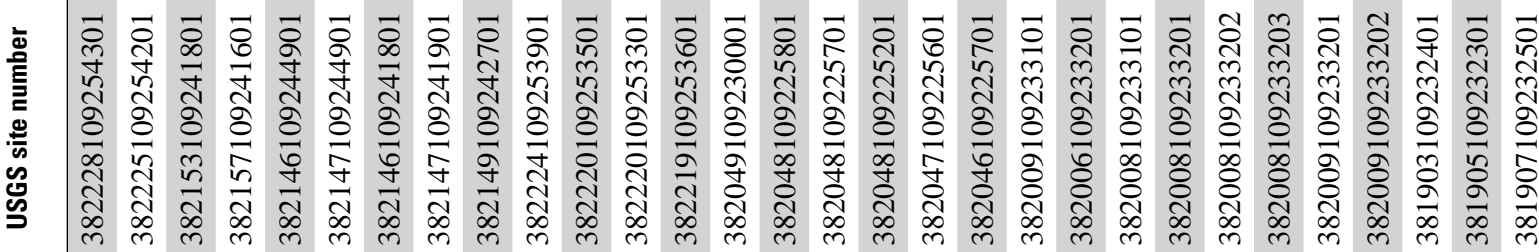

$\frac{\pi}{\pi} \frac{\pi}{0}$

党青要

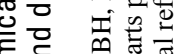

它灾

m. 혼

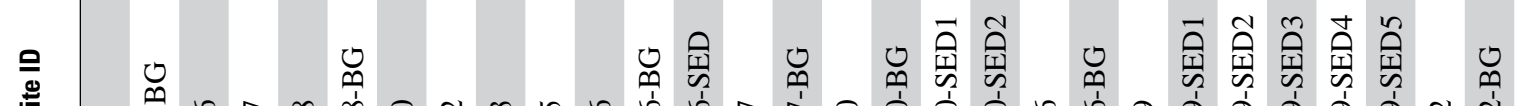

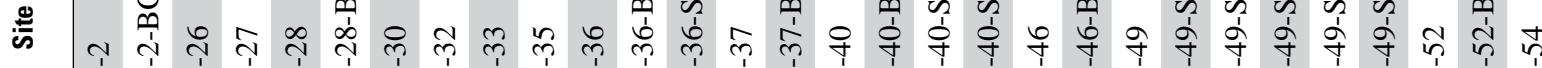

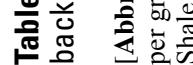

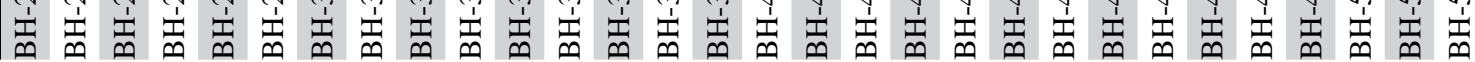




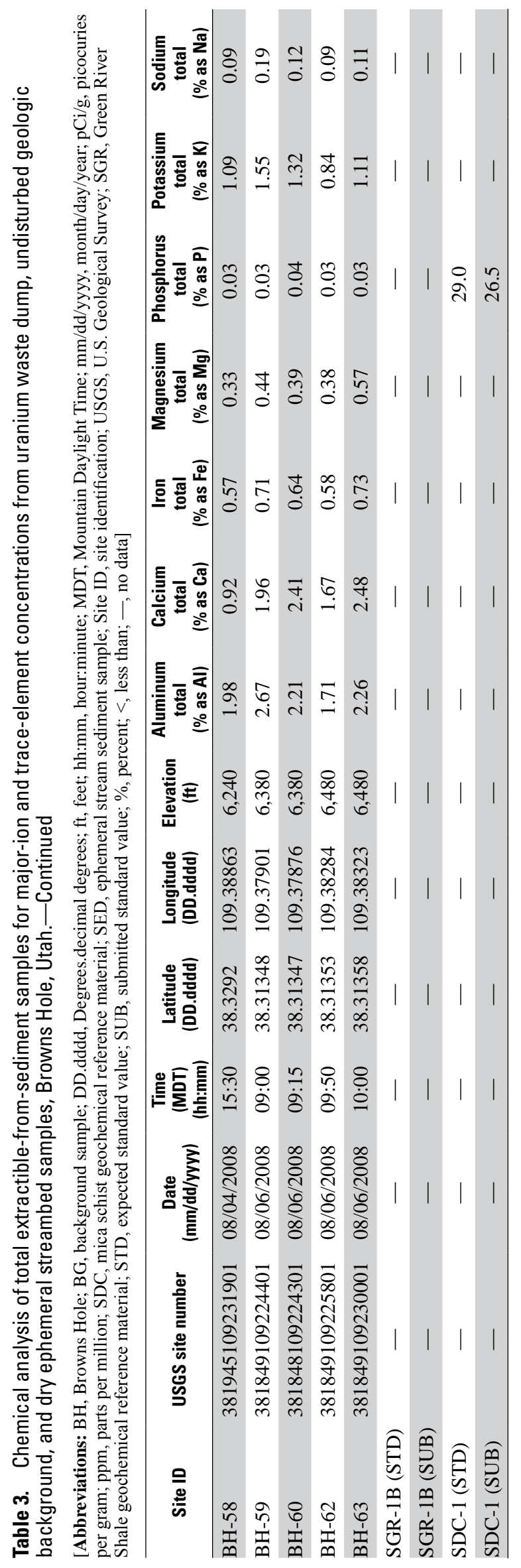




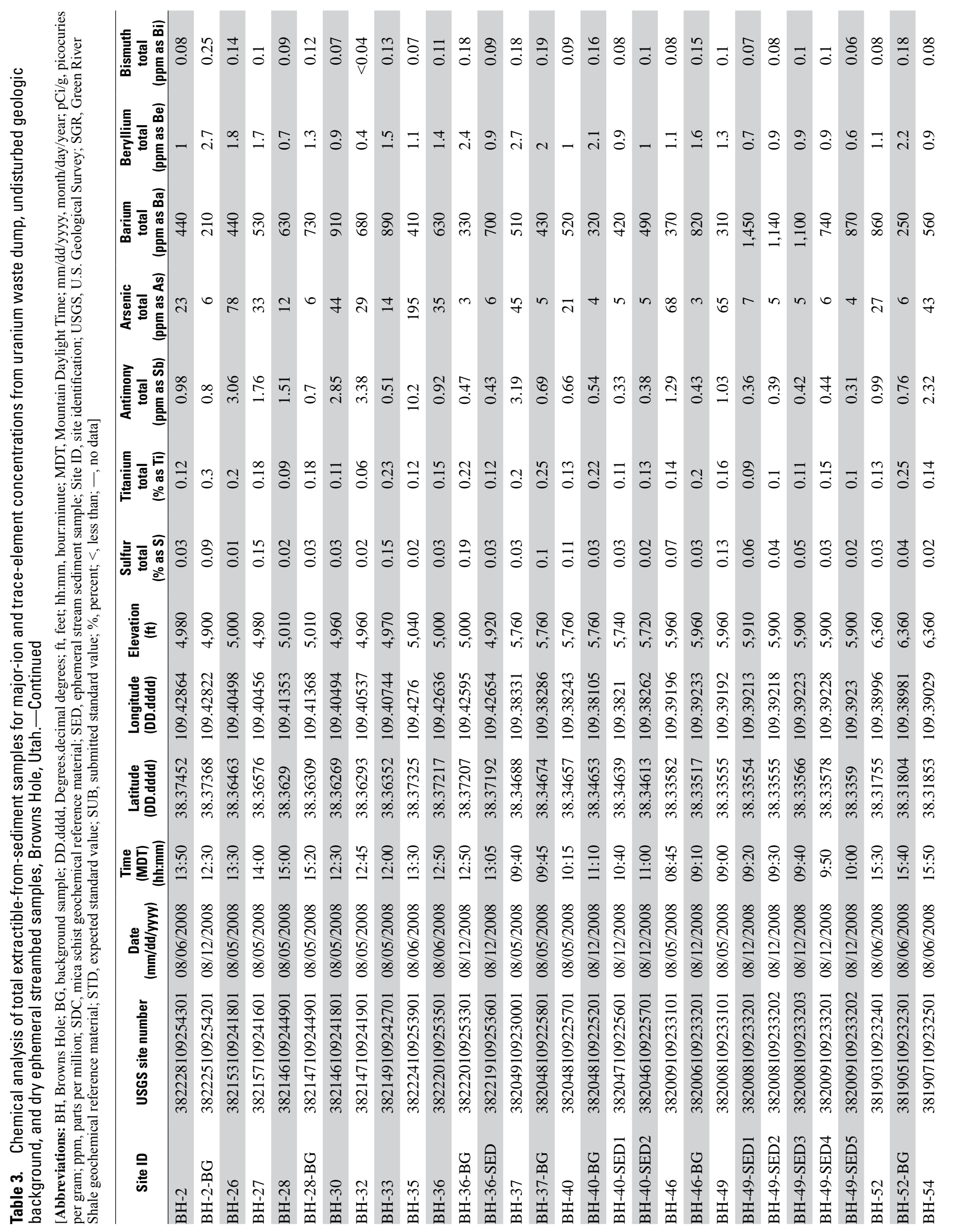




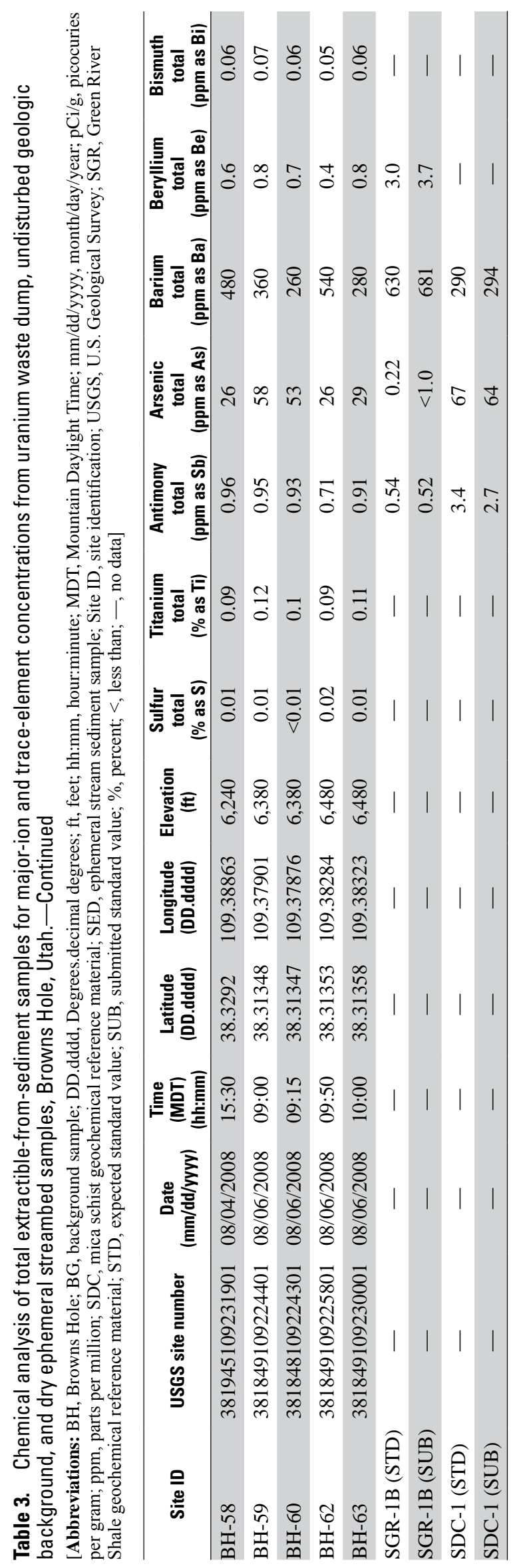




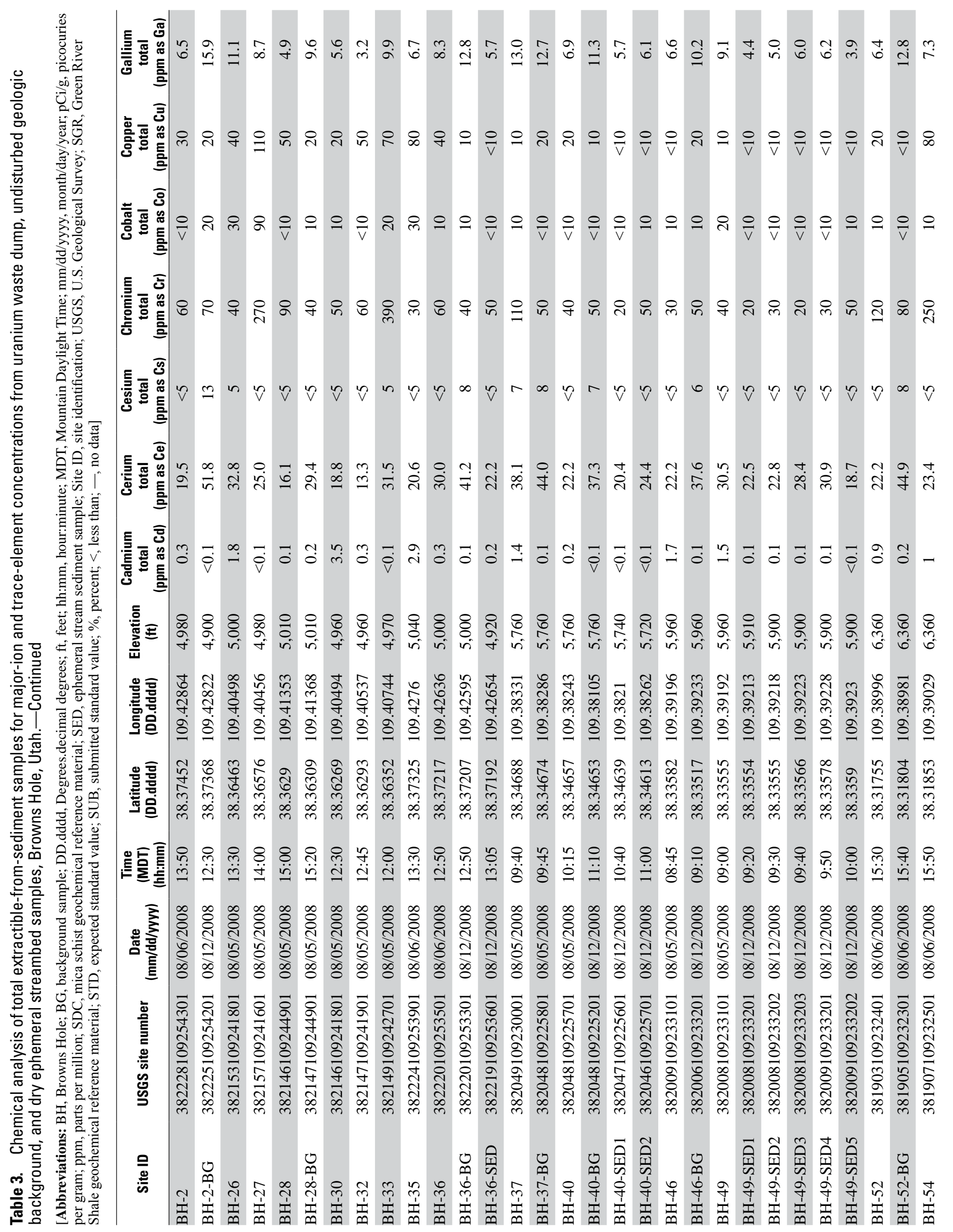




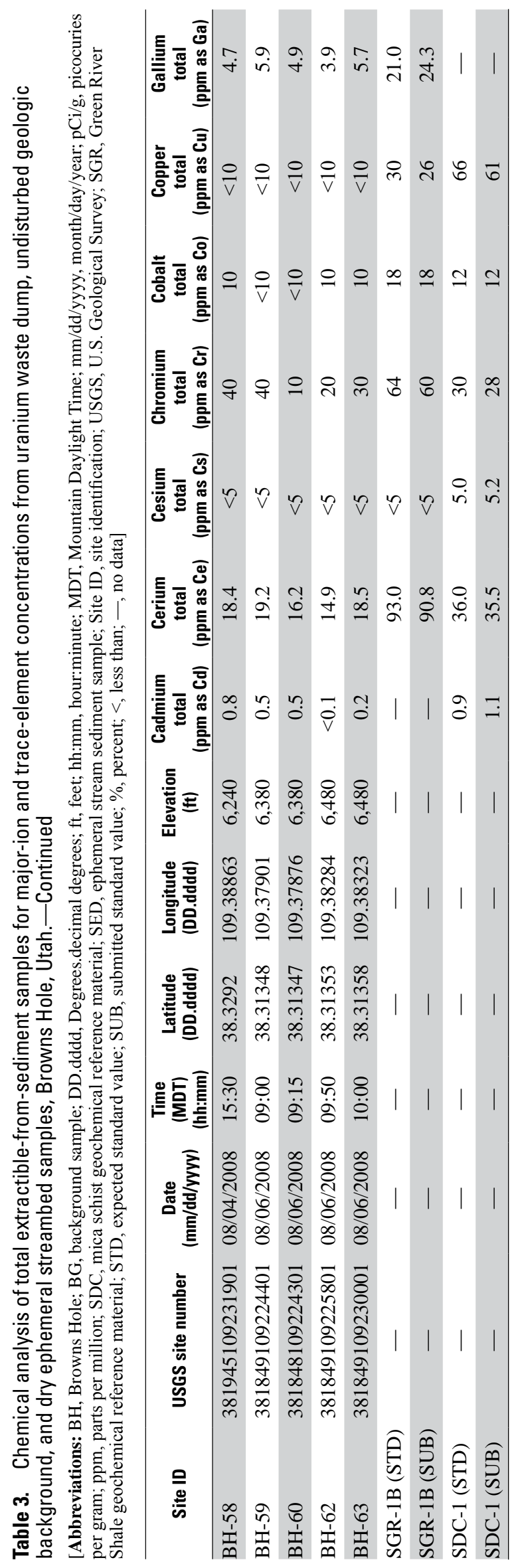




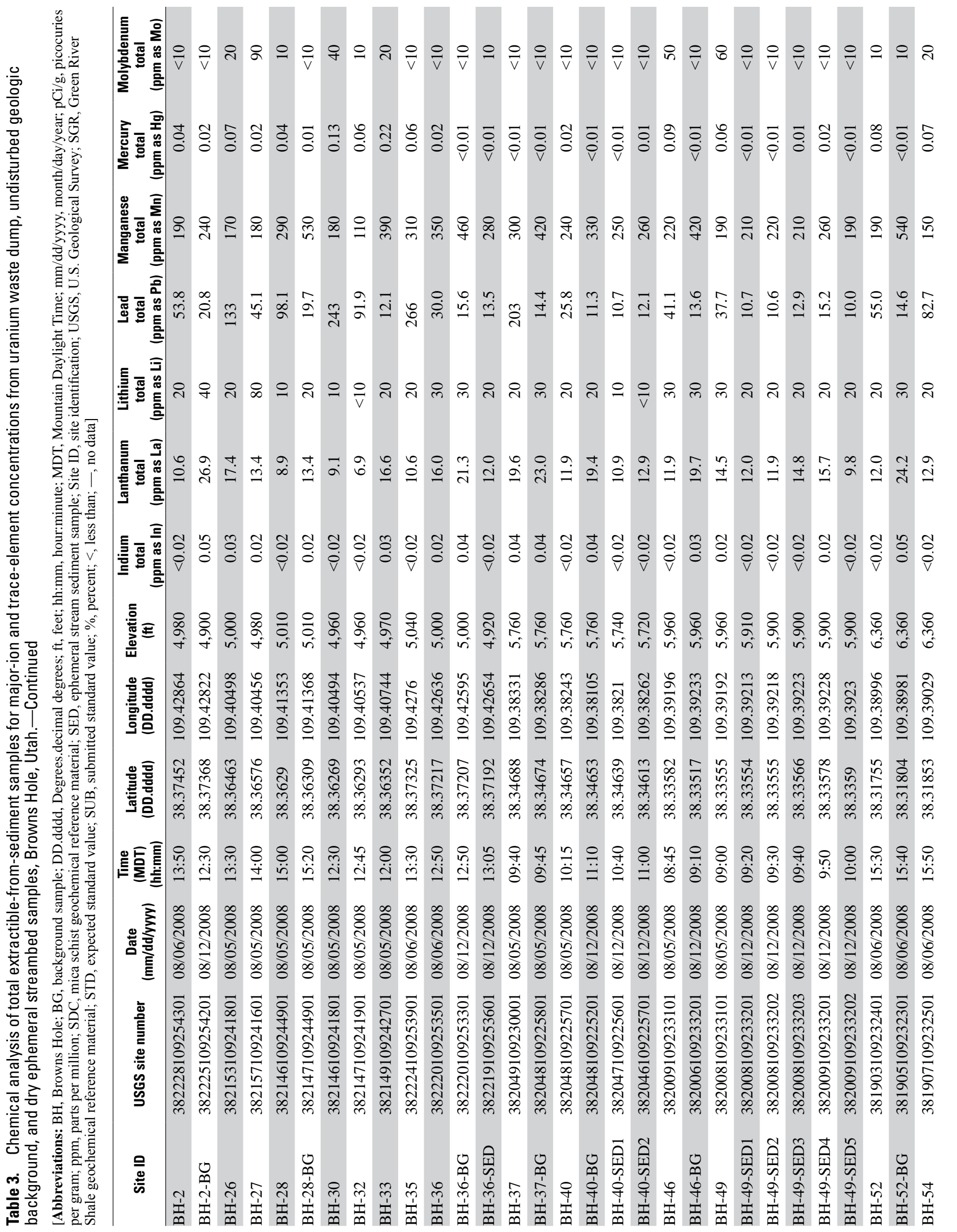




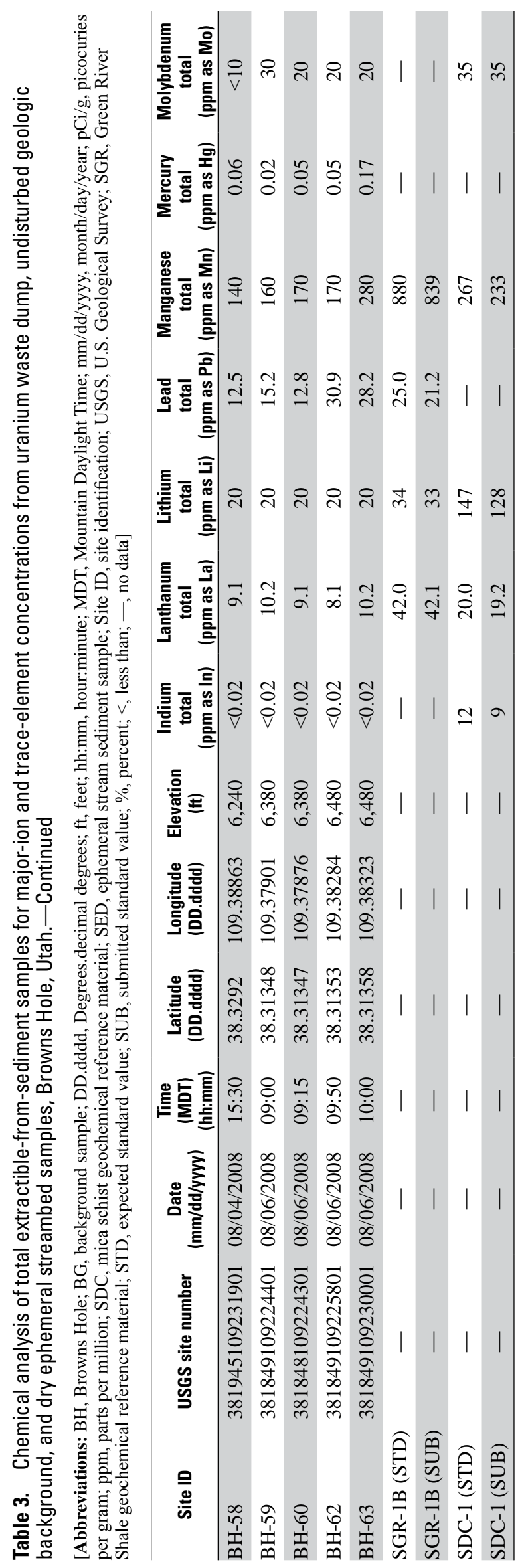




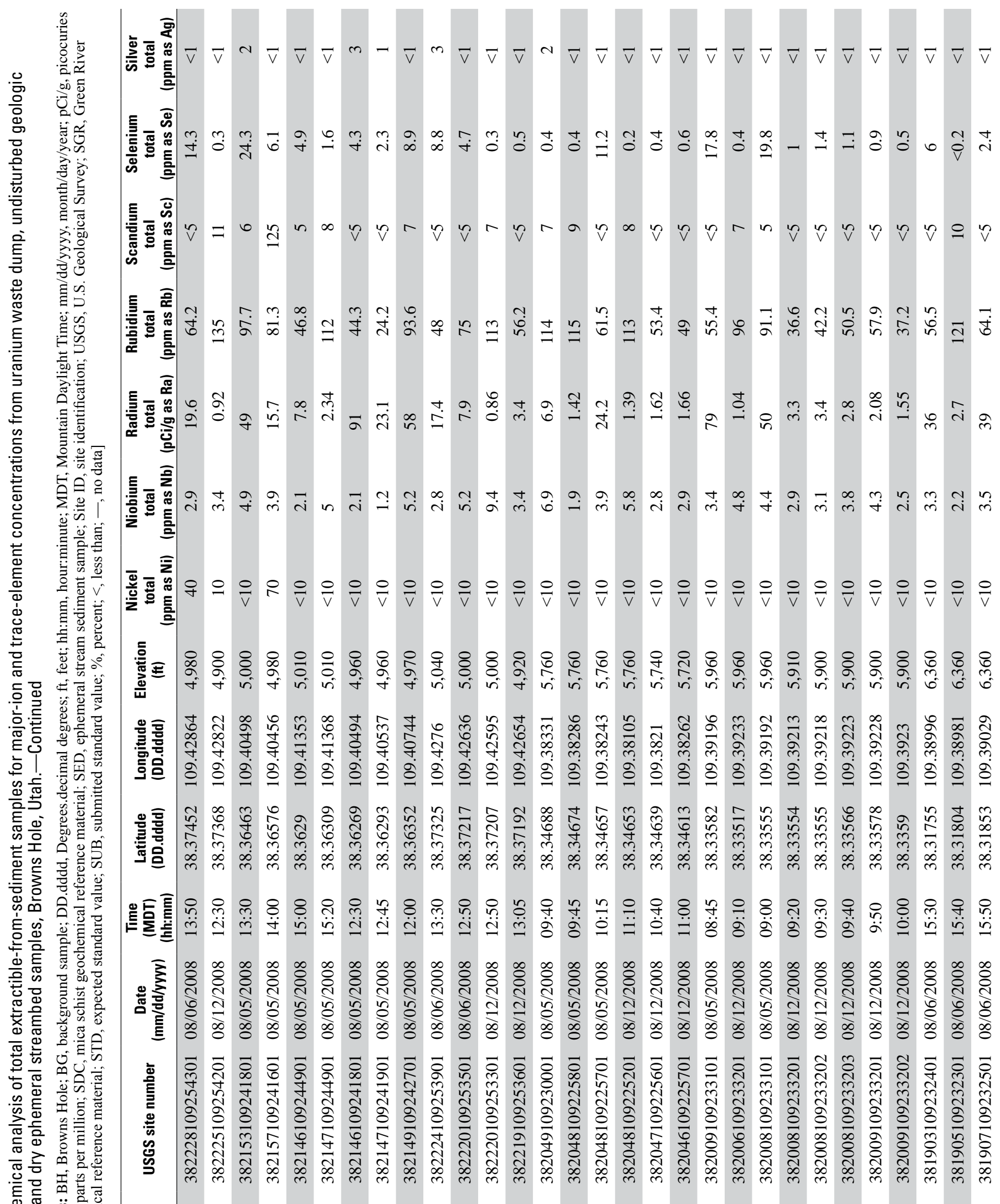

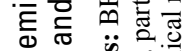

m

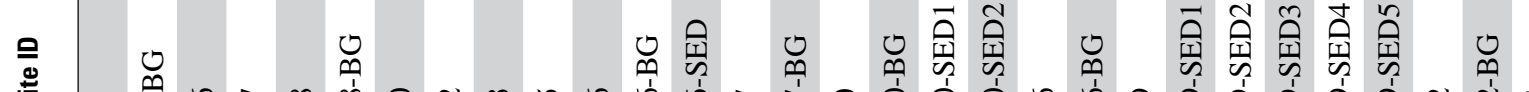

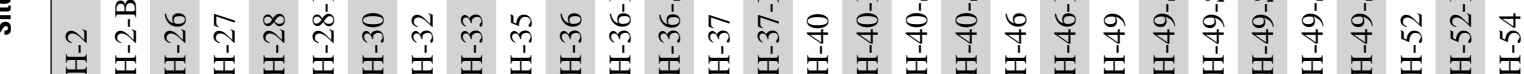

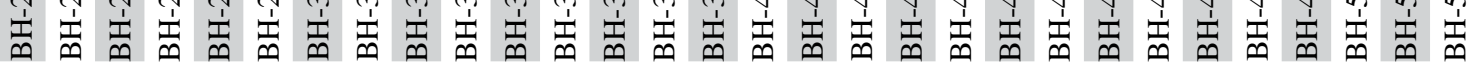




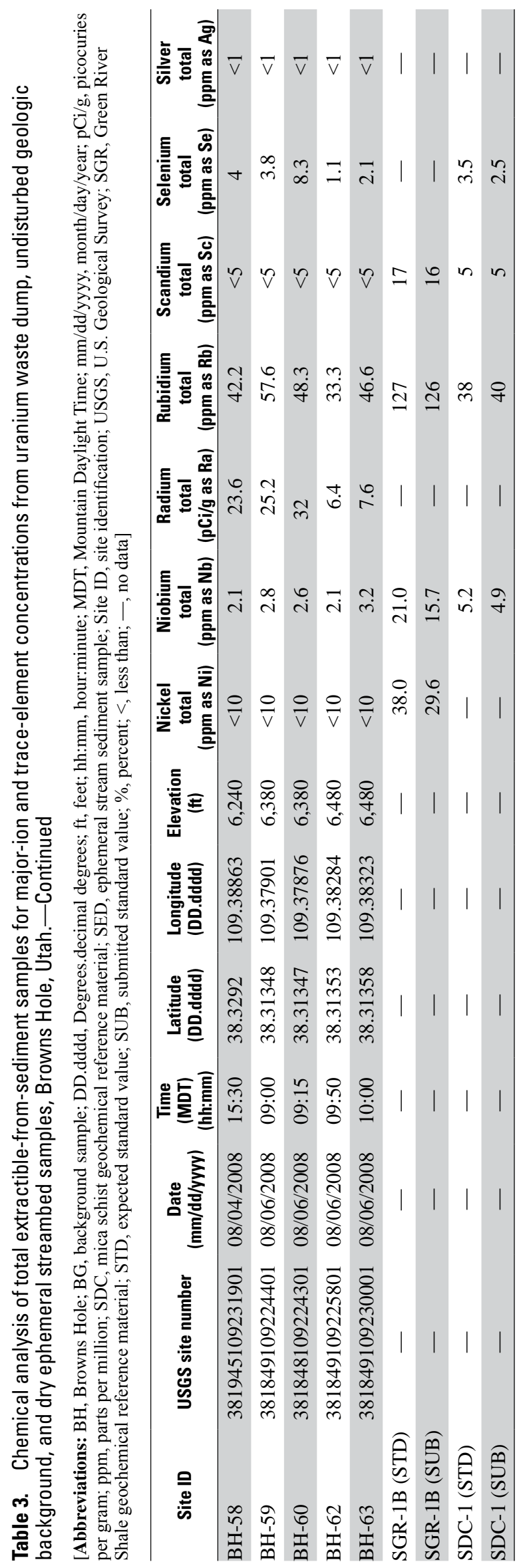




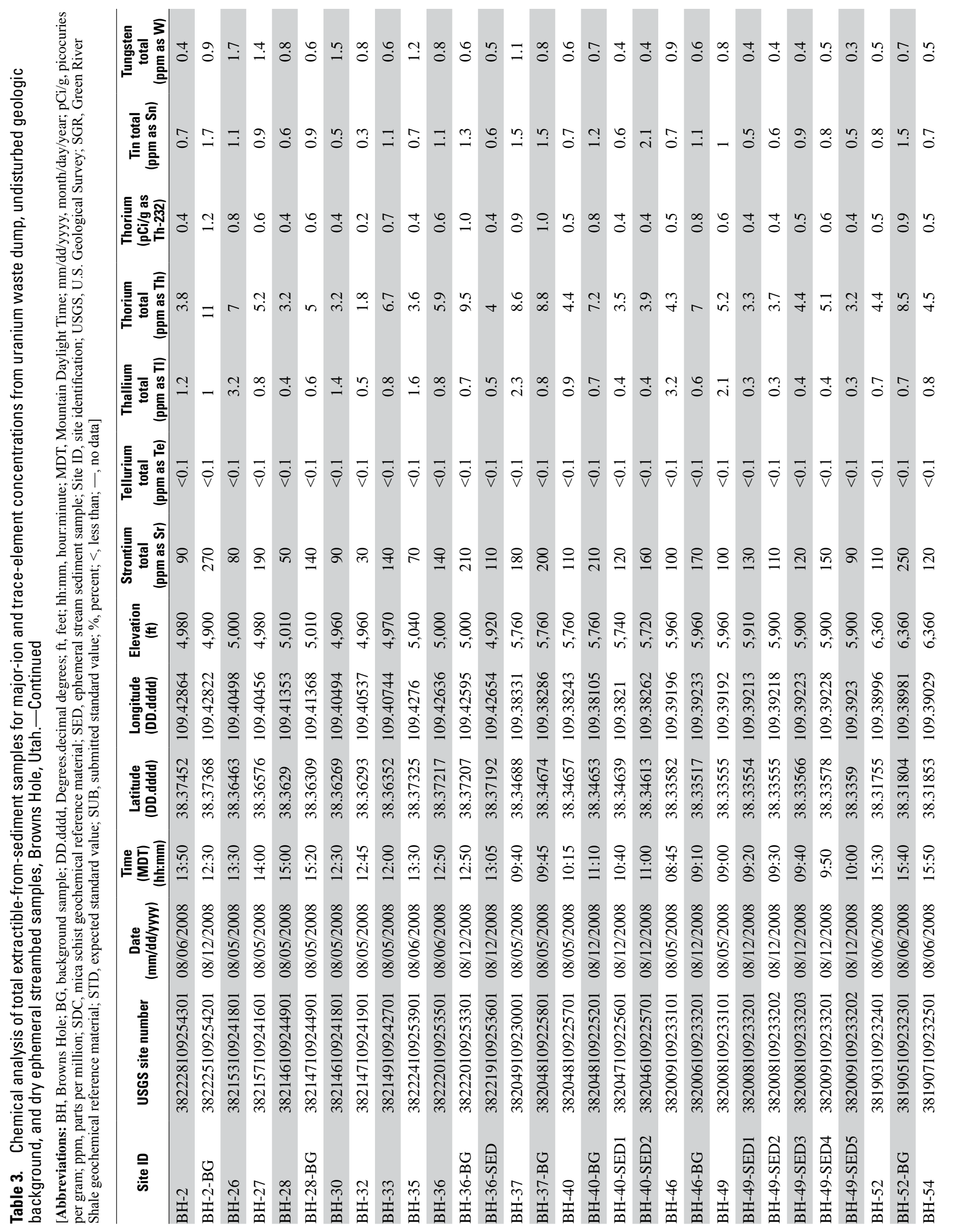




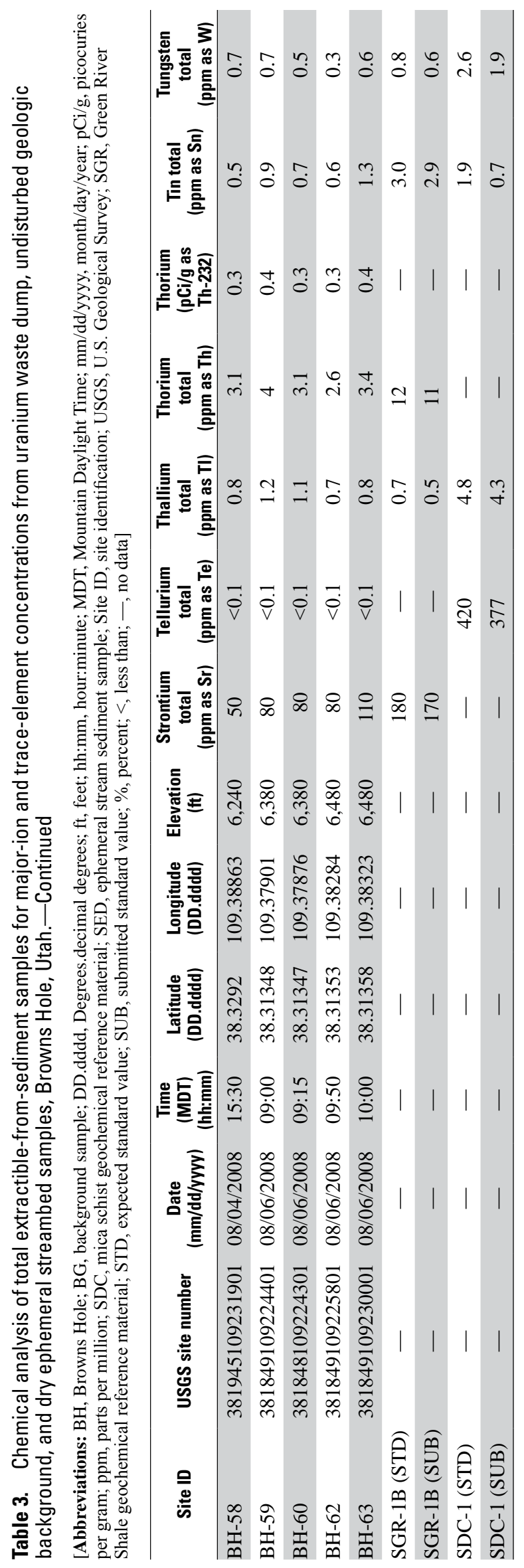




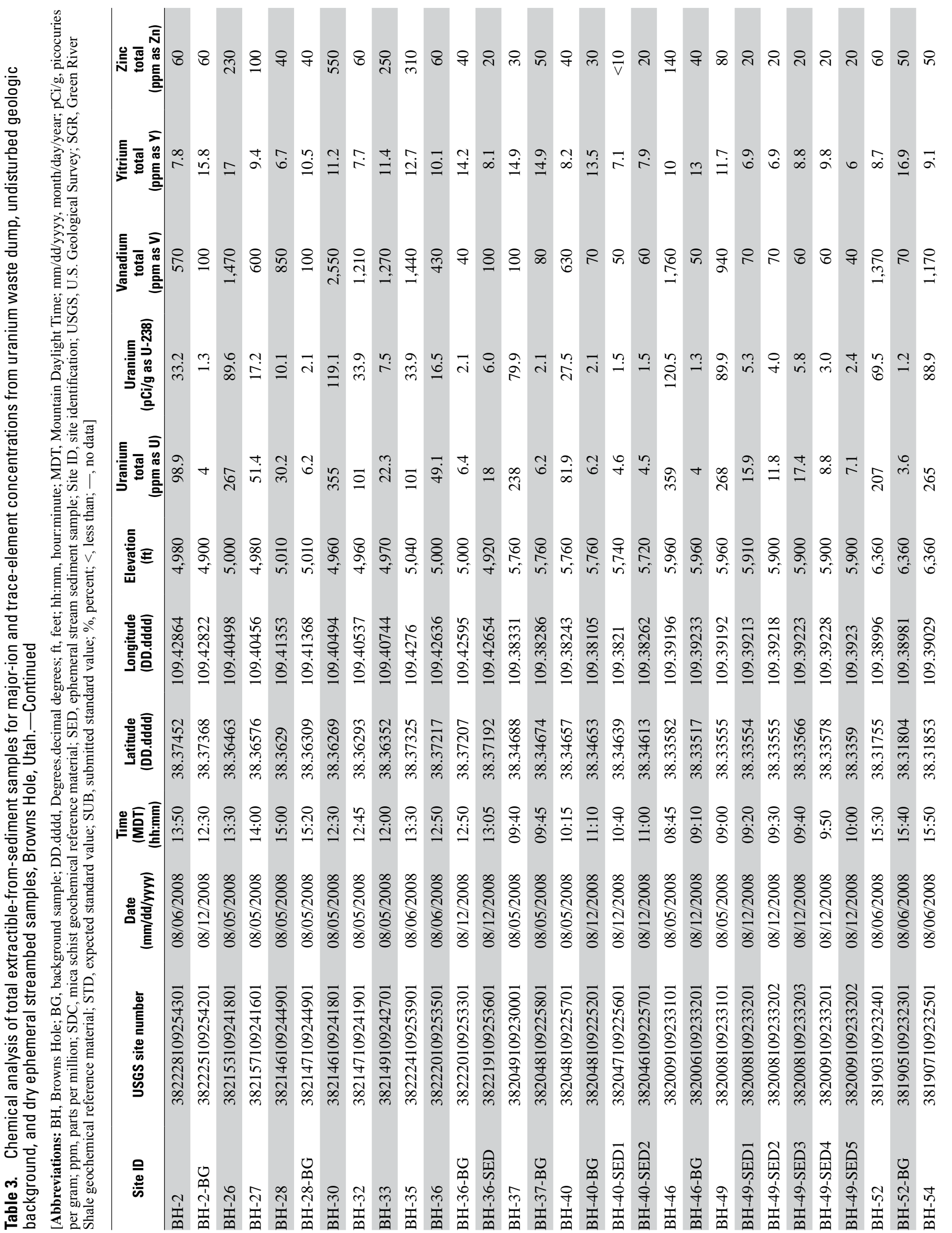




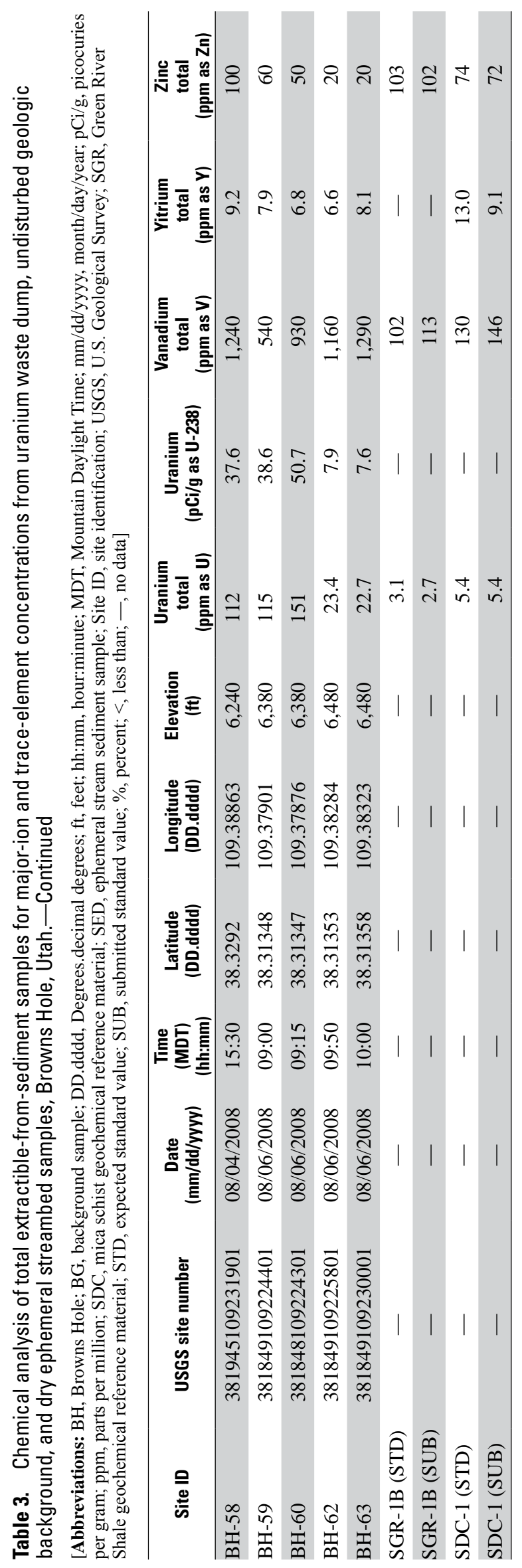




\section{References Cited}

Argonne National Laboratory, 2005, Natural decay series: uranium, radium, and thorium: Human Health Fact Sheet, August 2005, 4 p.

Briggs, P.H., 2002, The determination of forty elements in geological and botanical samples inductively coupled plasma-atomic emission spectrometry, in Taggart, J.E., Jr., ed., Analytical methods for chemical analysis of geologic and other materials: U.S. Geological Survey Open-File Report 02-223-G, p. G1-18.

Brown, Z.A., O’Leary, R.M., Hageman, P.L., and Crock, J.G., 2002, Mercury in water, geologic, and plant materials by continuous flow-cold vapor-atomic absorption spectrometry, in Taggart, J.E., Jr., ed., Analytical methods for chemical analysis of geologic and other materials: U.S. Geological Survey Open-File Report 02-223-M, p. M1-9.

Crock, J.G., Lichte, F.E., and Briggs, P.H., 1983, Determination of elements in National Bureau of Standards geological reference materials SRM 278 obsidian and SRM 688 basalt by inductively coupled plasma-atomic emission spectroscopy: Geostandards Newsletter, v. 7, no. 2, p. 335-340.

Gloyn, R.W., Morgan, C.D., Tabet, D.E., Blackett, R.E., Tripp, B.T., and Lowe, M., 1995, Mineral, energy, and groundwater resources of San Juan County, Utah: Utah Geological Survey Special Study 86, 39 p.

Hageman, P.L., and Briggs, P.H., 2000, A simple field leach test for rapid screening and qualitative characterization of mine uranium waste dump material on abandoned mine lands: Fifth International Conference on Acid Rock Drainage, International Conference on Acid Rock Drainage, Denver, Colorado, May 21-24, 2000, Proceedings, p. 1463-1475.

Hageman, P.L., Brown, Z.A., and Welsch, E., 2002, Arsenic and selenium by flow injection or continuous flow-hydride generation-atomic absorption spectrophotometry, in Taggart, J.E., Jr., ed., Analytical methods for chemical analysis of geologic and other materials: U.S. Geological Survey Open-File Report 02-223-L, p. L1-7.

Kenney, T.A., Wilkowske, C.D., and Wright, S.J., 2007, Methods for estimating magnitude and frequency of peak flows for natural streams in Utah: U.S. Geological Survey Scientific Investigations Report 2007-5158, 28 p.

Natural Resources Conservation Service, 1998, Utah annual precipitation [map]: scale 1:1,000,000 Source 1008501.

Ries III, K.G., Steeves, P.A., Coles J.D., Rea, A.H., and Stewart, D.W., 2004, StreamStats: A U.S. Geological Survey web application for stream information: U.S. Geological Survey Fact Sheet 2004-3115.
Smith, K.S., Ramsey, C.A., and Hageman, P.L., 2000, Sampling strategy for the rapid screening of mine-waste dumps on abandoned mine lands: Fifth International Conference on Acid Rock Drainage, Denver, Colorado, May 21-24, 2000, Proceedings, p. 1453-1461.

Stearn, T.W. and Stieff, L.R., 1959, Geochemistry and mineralogy of the Colorado Plateau uranium ores: Part 13. Radium-uranium equilibrium and radium-uranium ages of some secondary minerals: U.S. Geological Survey Professional Paper 320, p. 151-156.

U.S. Environmental Protection Agency, 2010, Approved general-purpose methods, Method 903.0, accessed March 25, 2010, at URL http://www.epa.gov/waterscience/methods/method/files/903_0.pdf.

U.S. Environmental Protection Agency, 2008, Technologically enhanced naturally occurring radioactive materials from uranium mining, v. 2: Investigation of potential health, geographic, and environmental issues of abandoned uranium mines, accessed March 4, 2010, at URL http://www.epa. gov/rpdweb00/docs/tenorm/402-r-08-005-volii/402-r-08005-v2.pdf.

U.S. Environmental Protection Agency, 2007a, Drinking water contaminants, accessed January 22, 2007, at URL http:// www.epa.gov/safewater/contaminants/index.html.

U.S. Environmental Protection Agency, 2007b, Current national recommended water-quality criteria for aquatic life, accessed January 21, 2007, at URL http://www.epa.gov/ waterscience/criteria/wqcriteria.html.

U.S. Environmental Protection Agency, 1997a, Memorandum -Establishment of cleanup levels for CERCLA sites with radioactive contamination: OSWER No. 9200.4-18, Washington, D.C., August 1997.

U.S. Environmental Protection Agency, 1997b, Exposure factors handbook: Washington, D.C., EPA/600/P-95/002F a-c, 1997.

U.S. Geological Survey, 2006, Collection of water samples (ver. 2.0): U.S. Geological Survey Techniques of WaterResources Investigations, book 9, chap. A4, September, accessed March 23, 2010, at URL http://pubs.water.usgs. gov/twri9A4/.

Yu, C., Loureiro, C., Cheng, J.J., Jones, L.G., Wang, Y.Y., Chia, Y.P., and Faillance, E., 1993, Data collection handbook to support modeling impacts of radioactive material in soil: Environmental Assessment and Information Sciences Division, Argonne National Laboratory, Argonne, Illinois, 1993. 

